\title{
A review of Indigenous knowledge and participation in environmental monitoring
}

\author{
Kim-Ly Thompson ${ }^{1}$, Trevor C. Lantz ${ }^{1}$ and Natalie C. Ban ${ }^{1}$
}

\begin{abstract}
There is a growing interest by governments and academics in including Indigenous knowledge alongside scientific knowledge in environmental management, including monitoring. Given this growing interest, a critical review of how Indigenous peoples have been engaged in monitoring is needed. We reviewed and analyzed the academic literature to answer the following questions: How have Indigenous peoples participated in environmental monitoring, and how has their participation influenced monitoring objectives, indicators, methods, and monitoring outcomes? We also summarized how this literature discussed power, governance, and the use of both Indigenous and scientific knowledge in environmental monitoring efforts. We found that the literature most often characterized participation as data collection, and that higher degrees of participation and power held by Indigenous peoples in environmental monitoring leads to initiatives that have different objectives, indicators, and outcomes than those with heavier involvement of external groups. Our review also showed that a key challenge of conducting effective monitoring that leverages both Indigenous knowledge systems and science is the power imbalances that uncouple Indigenous monitoring efforts from management. We encourage future initiatives to carefully consider the ways in which power and governance shape their programs and the ability of their monitoring to lead to meaningful management actions.
\end{abstract}

Key Words: adaptive management; community-based monitoring; conservation; governance; participatory research; resource management; traditional ecological knowledge

\section{INTRODUCTION}

All human populations interact with the ecosystems surrounding them in some form or other. These interactions, whether they be hunting and harvesting available fauna and flora, agriculture, or nonrenewable resource extraction, involve some degree of management (Lertzman 2009). In contemporary times, the necessity of managing ecosystems and the way people interact with them is particularly evident for adapting to environmental change, mitigating industrial activity, and conserving biodiversity. A key component of environmental management is monitoring - the act of detecting and analyzing changes within a system in order to inform appropriate management responses (Lindenmayer and Likens 2010). Research in recent decades has demonstrated that environmental monitoring, when properly designed and linked to management bodies, can be done by local people as effectively as by academic or professional scientists, with the added benefits of being less expensive and increasing the likelihood of local people accepting resulting management actions (Danielsen et al. 2005, 2014a). Monitoring of indicators that are relevant to local objectives and are carried out by local people has been termed "community-based monitoring" (CBM) (Danielsen et al. 2009).

Alongside the acceptance of community-based monitoring is an increasing interest by governments and academics in including Indigenous knowledge alongside scientific knowledge in environmental management, including monitoring (United Nations Conference on Environment and Development 1992, Berkes et al. 2000, Huntington 2000, Ban et al. 2018, Fisheries and Oceans Canada 2020). Indigenous knowledge is commonly defined as "...a cumulative body of knowledge, practice, and belief, evolving by adaptive processes and handed down through generations by cultural transmission, about the relationship of living beings (including humans) with one another and with their environment" (Berkes 2012). Some synonyms of Indigenous knowledge found within the academic literature include traditional ecological knowledge (e.g., Eckert et al. 2017), local and traditional knowledge (e.g., Thornton and Scheer 2012), Indigenous ecological knowledge (e.g., Gratani et al. 2011), and folk knowledge (e.g., Gadgil et al. 2000). The most appropriate phrase to use has been thoroughly debated without clear resolution (e.g., Nadasdy 1999, Berkes 2012, Wyndham 2017). There is also some contention about the difference between local knowledge and Indigenous knowledge (e.g., Davis and Ruddle 2015). We differentiate between local knowledge and Indigenous knowledge based on the histories, socio-political contexts, and self-identification of those creating and holding the knowledge (Corntassel 2003), whereby Indigenous peoples can be understood as peoples with "Historical continuity with precolonial or pre-settler societies; strong links to territories and surrounding natural resources; distinct social, economic or political systems; form non-dominant groups of society; resolved to maintain and reproduce their ancestral environments and systems as distinctive peoples and communities" (United Nations Permanent Forum on Indigenous Issues, n.d.).

We use the term Indigenous knowledge to refer to a way of knowing that has evolved from the relationship between many generations of Indigenous people and their traditional territories (Wilson 2001, Turner and Berkes 2006, Simpson 2014). These lived relationships involve resource use, stewardship, oral histories, and spirituality, and often guide political governance systems (e.g., Greening 2017). We emphasize that such knowledge systems are not static. Rather, they evolve within ever-changing ecological, cultural, and political contexts (McCullough and Matson 2011, Davis and Ruddle 2015). Further, given their placebased nature, they are diverse in the specificity of their contentthere are as many distinct Indigenous knowledges as there are 
distinct Indigenous peoples. For example, the traditional knowledge of Inuit people, called Inuit Qaujimajatuqangi, has different content than that of Mâtauranga Maori, the traditional knowledge of Maori people. Reasons for using both Indigenous knowledge and science to inform monitoring and management include the complementarity of the differences between the two knowledge systems, which can enrich collective ecological knowledge (Moller et al. 2004, Ban et al. 2018).

There are variations in how local people participate in CBM. Danielsen et al. (2009) described a typology of local participation in CBM: (1) externally driven, professionally executed, (2) externally driven with local data collectors, (3) collaborative monitoring with external data interpretation, (4) collaborative monitoring with local data interpretation, and (5) autonomous local monitoring. A recent review by Turreira-García et al. (2018) further indicated that many community-based monitoring initiatives that label themselves as "participatory" involve local people mainly as cost-effective data collectors. When Indigenous people participate in management initiatives driven by institutions with histories of enabling colonization (i.e., state governments, universities), there is a risk of such superficial participation entrenching existing power imbalances and leading to the misinterpretation, misappropriation, or tokenization of knowledge (Nadasdy 1999, Simpson 2000, Bohensky and Maru 2011). However, when Indigenous people lead collaborative monitoring and management, these can be ways of asserting sovereignty and governance (e.g., Kotastka 2013, Housty et al. 2014, Frid et al. 2016, Wilson et al. 2018).

Given increasing interest and mandates (e.g., Fisheries and Oceans Canada 2016) to include Indigenous knowledge in environmental management, a critical analysis of the participation of Indigenous peoples in CBM is necessary. We review and analyze the academic literature to answer the following questions: How have Indigenous peoples participated in environmental monitoring, and how has their participation influenced monitoring objectives, indicators, methods, and monitoring outcomes? Further, given the colonial realities in which many Indigenous peoples are immersed (e.g., Dhillon 2015), we summarize how this literature discusses power, governance, and the use of both Indigenous and scientific knowledge in environmental monitoring efforts. Finally, we synthesize challenges and recommendations in order to inform individuals and organizations that seek to engage in future monitoring initiatives led by, or in collaboration with, Indigenous peoples.

This review was sparked by our collaborative work with the Gitga'at First Nation in coastal British Columbia, Canada to inform the design of a CBM program based on the knowledge of their harvesters (Thompson et al. 2019). In the early phases of our work, we became familiar with reviews of community-based monitoring (e.g., Kouril et al. 2016). However, we found that an analysis of Indigenous peoples' participation and knowledge in environmental monitoring was missing. Our work is informed by our positions as non-Indigenous scholars who conduct ecological and ethnoecological research in partnerships with Indigenous peoples in coastal British Columbia (NCB, KLT) and in the Northwest Territories (TCL) of Canada.

\section{METHODS}

\section{Literature search}

We searched Thomson-Reuter's Web of Knowledge using the terms "Indigenous environmental monitoring", and "Indigenous resource monitoring", then ["environmental monitoring" OR "ecological monitoring" OR "biological monitoring" OR "resource monitoring"] AND ["Indigenous Knowledge" OR "Traditional Ecological Knowledge" OR "Aboriginal Knowledge"]. Our search included papers published up to the final search date of November 20, 2019.

We read the abstracts of our search results, and selected publications for detailed review that met all the following criteria:

1. papers described a monitoring initiative. Many papers we reviewed discussed environmental management and indicated that monitoring would be useful but did not describe the proposed monitoring;

2. papers described monitoring by or with Indigenous people. Several reviews have examined the role of local people in monitoring their environments (e.g., Danielsen et al. 2014a, Kouril et al. 2016);

3. papers described monitoring over a period of time. We excluded papers that described "snapshots" of knowledge; and

4. publications were peer-reviewed. Academic papers in journals or that were presented at conferences were included. We did not include grey literature in this review.

Several of the results that appeared using our search terms included work done by, or in collaboration with, Inuit, Maori, Australian Aboriginal, and Sami peoples. In order to test whether our generic search terms may have missed more literature that was specific to these groups, we added the terms "Inuit", "Maori", and "Sami" as part of a separate search. We found that we missed only three papers with our generic search terms. It was not feasible to search for all Indigenous groups by name, and we suspect that initiatives involving some groups were not captured in this review. Further, given the skill set of our research team, we conducted our search in English only; thus, we surely missed relevant papers published in other languages. However, we believe that our review is a good starting point for characterizing the literature.

\section{Content analysis}

We analyzed the content of each paper according to a predetermined list of themes and guiding questions (Table 1). Relevant text was copied and pasted into a Microsoft Excel workbook, and then coded in separate worksheets. We coded the content related to questions 5 and 7 and 15-22 using an emergent approach whereby we discerned codes as they arose. We then grouped these codes into themes (Fereday and Muir-Cochrane 2006). We coded the content related to question 6 using a directed approach (Hsieh and Shannon 2005) informed by socialecological systems and resilience theory (Folke 2006, Janssen et al. 2007, Ostrom 2009), whereby we categorized indicators as ecological (i.e., biological, physical, or chemical), social (i.e., human processes, such as spirituality, language), and socialecological (i.e., interactions between humans and the natural world, such as hunting activities). KLT led the coding, while NCB and TCL reviewed codes. 
Table 1. Themes and guiding questions for literature review and analysis.

\begin{tabular}{|c|c|c|}
\hline Themes & $\begin{array}{l}\text { Question } \\
\text { number }\end{array}$ & Guiding questions \\
\hline \multirow{7}{*}{$\begin{array}{l}\text { Monitoring } \\
\text { activities }\end{array}$} & 1 & What country is monitoring done in? \\
\hline & 2 & Which Indigenous peoples are involved? \\
\hline & 3 & Are there other groups involved? \\
\hline & 4 & What bioregions are being monitored? \\
\hline & 5 & What are the monitoring objectives? \\
\hline & 6 & What indicators are used to monitor? \\
\hline & 7 & What methods are used to monitor the indicators? \\
\hline \multirow{10}{*}{$\begin{array}{l}\text { Participation, } \\
\text { outcomes, and } \\
\text { governance }\end{array}$} & 8 & Who initiated the project? \\
\hline & 9 & Who set the project objectives? \\
\hline & 10 & Who designed the data collection methods? \\
\hline & 11 & Who collects data? \\
\hline & 12 & Who owns the data? \\
\hline & 13 & Who analyzes and interprets data? \\
\hline & 14 & Who uses data for management decisions? \\
\hline & 15 & $\begin{array}{l}\text { What are the outcomes of monitoring for } \\
\text { Indigenous peoples and territories? }\end{array}$ \\
\hline & 16 & How is governance discussed? \\
\hline & 17 & How are colonization and/or power discussed? \\
\hline \multirow{3}{*}{$\begin{array}{l}\text { Multiple } \\
\text { knowledge } \\
\text { systems }\end{array}$} & 18 & $\begin{array}{l}\text { What are the explicit contributions of Indigenous } \\
\text { knowledge to monitoring? }\end{array}$ \\
\hline & 19 & $\begin{array}{l}\text { What are the explicit contributions of western } \\
\text { science to monitoring? }\end{array}$ \\
\hline & 20 & $\begin{array}{l}\text { How is the combination of Indigenous knowledge } \\
\text { and western science discussed? }\end{array}$ \\
\hline \multirow{2}{*}{$\begin{array}{l}\text { Challenges and } \\
\text { recommendations }\end{array}$} & 21 & What monitoring challenges are discussed? \\
\hline & 22 & What monitoring recommendations are given? \\
\hline
\end{tabular}

\section{Analysis of participation}

For each monitoring initiative described in the literature, we divided monitoring activities into six stages: (1) initiating the project, (2) setting objectives, (3) designing data collection methods, (4) collecting data, (5) analyzing and interpreting data, and (6) making management decisions. These were linked to guiding questions $8-14$ (Table 1). We then assigned a governance weight to each of these monitoring activities (Table 2). These scores were informed by Wilson et al.'s (2018) typology of Indigenous governance in monitoring. We then scored each monitoring activity according to who participated in each phase (Table 3). For each monitoring initiative, we calculated weighted participation (WP) according to Eq. 1:

$$
W P=\sum_{M 1}^{M 6} g * p
$$

where WP is the weighted participation, M1 is the first phase of monitoring (i.e., initiating the project), and M6 is the last phase of the monitoring (making management decisions), $g$ is governance weight, and $p$ is the participation score.

We then binned initiatives into four categories across the range of weighted participation scores, inspired by Wilson et al.'s (2018) and Danielsen et al.'s (2009) categorizations of participation in CBM. Though these initiatives exist along a spectrum, these categories can be broadly defined as IP1: Externally driven with Indigenous people as data collectors; IP2: Collaborative with Indigenous people playing some role in design and execution; IP3: Collaborative with Indigenous people playing a strong role in design, execution, and management; IP4: Autonomous monitoring by Indigenous people with some external support.
Table 2. Monitoring activities and associated governance weights

\begin{tabular}{ll}
\hline \hline Monitoring activity & $\begin{array}{l}\text { Governance } \\
\text { weight }(g)\end{array}$ \\
\hline M1. Initiating monitoring project & 2 \\
M2. Setting monitoring objectives & 5 \\
M3. Designing data collection methods & 4 \\
M4. Collecting data & 1 \\
M5. Analyzing and interpreting data & 3 \\
M6. Making management decisions & 6 \\
\hline
\end{tabular}

Table 3. Groups participating in monitoring activities and associated participation score

\begin{tabular}{ll}
\hline \hline Group(s) participating monitoring activity & $\begin{array}{l}\text { Participation } \\
\text { score }(p)\end{array}$ \\
\hline Indigenous group only & 4 \\
Collaboration between external and Indigenous group & 3 \\
External group only & 2 \\
Not indicated & 1 \\
\hline
\end{tabular}

\section{Linking participation to monitoring objectives, indicators, methods, and outcomes}

We sought to analyze whether there was a connection between the degree of Indigenous participation and the monitoring objectives, indicators, methods, and outcomes described in the literature. We did this by calculating the percentage of initiatives in each category of participation (IP1, IP2, IP3, IP4) that included the objectives, indicators, methods, and outcomes previously coded. We depicted the resulting data in radar diagrams.

\section{RESULTS}

\section{Search results}

Our literature search yielded 79 academic papers that met our selection criteria: 68 described at least one case study of Indigenous participation in environmental monitoring, and 11 were reviews. In total, the papers contained 77 case studies of monitoring initiatives that involved Indigenous people (Appendix 1, Table A1). Overall, academic literature about environmental monitoring and Indigenous peoples has been increasing since the late 1990s (Fig. 1).

The initiatives we reviewed included the participation of at least 82 distinct Indigenous peoples. This is a conservative number since some publications identified Indigenous peoples using general terms (i.e., First Nations, Australian Aboriginal) within which subgroups may self-identify. The initiatives took place in diverse bioregions and across at least 35 countries worldwide. The largest number of initiatives monitored Arctic regions $(n=37)$; freshwater systems $(n=26)$ and coastal/marine systems $(n=19)$ were also mentioned frequently (Fig. 2).

\section{Participation in monitoring activities}

The amount of detail reported on who participated varied for each phase of monitoring (Fig. 3). Most initiatives $(90 \%, n=69)$ indicated who participated in data collection, while just over half $(55 \%, n=42)$ indicated who set the monitoring objectives. Indigenous people were most frequently involved in collecting 
data, either independently $(39 \%, n=30)($ e.g., Sheil et al. 2015) or in partnership with researchers or scientists $(48 \%, n=37)(\mathrm{e}$. g., Dobbs et al. 2016). Indigenous peoples were also frequently reported as playing a role in designing data collection methods alongside collaborating researchers $(55 \%, n=42)$ (e.g., they were also frequently involved in analyzing data collected collaboratively [ $44 \%, n=34$ ] [e.g., Gearheard et al. 2011]). It is noteworthy that in the papers we reviewed, Indigenous peoples were infrequently reported as independently initiating monitoring programs (24\%, $n=19)$ (e.g., Kennett et al. 2010), setting project objectives (14\%, $n=11$ ) (e.g., Morishige et al. 2018), designing data collection methods $(5 \%, n=4)$ (e.g., Sheil et al. 2015), analyzing and interpreting data $(16 \%, n=13)$ (e.g., Parlee et al. $2005)$, or making resulting management decisions $(24 \%, n=19)$ (e.g., Ens et al. 2010).

Fig. 1. Number of papers within literature on Indigenous peoples and environmental monitoring. Literature published up to November 2019 was reviewed.

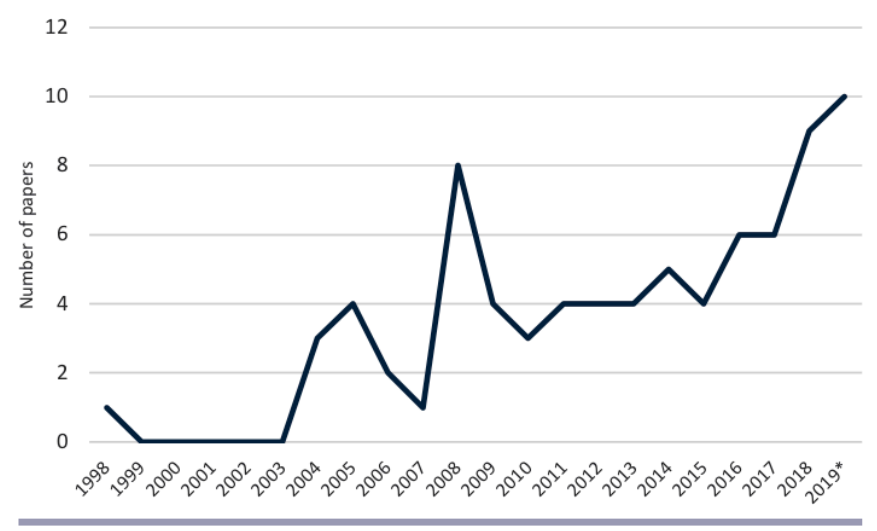

Fig. 2. Frequency of biogeographic regions listed within literature on Indigenous peoples and environmental monitoring.

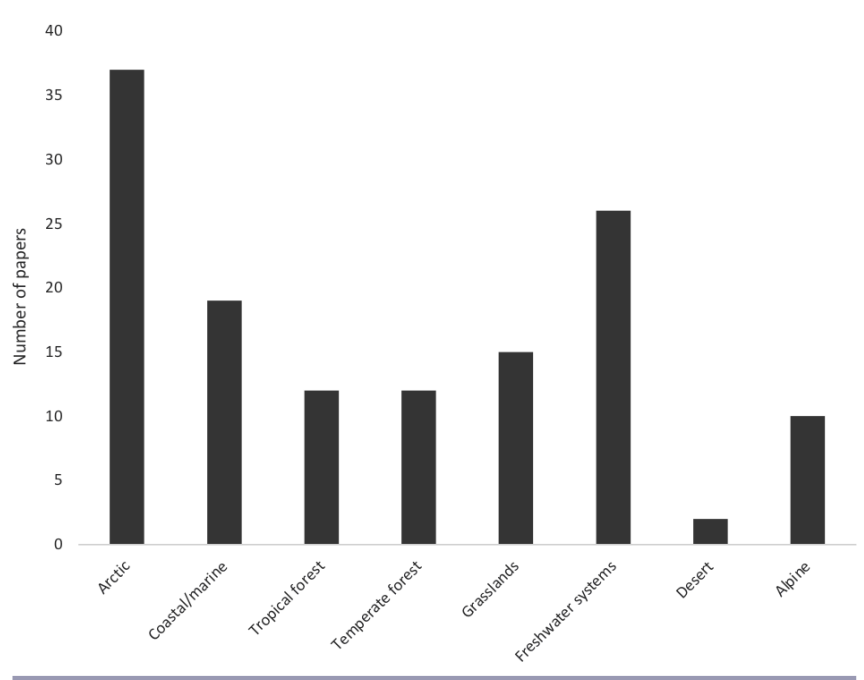

Fig. 3. Percentage of initiatives reviewed $(n=77)$ that indicated which groups participated in monitoring activities.

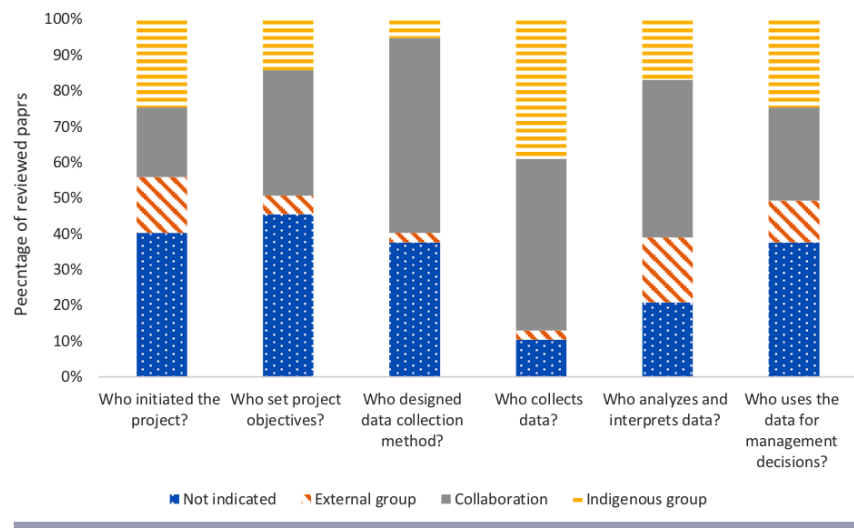

The infrequency of autonomous initiatives reported was also reflected in the distribution of weighted participation scores. Monitoring initiatives in the literature were most frequently reported as collaborative, with Indigenous people involved in their design, execution, and management (IP3) $(40 \%, n=31)$, or externally driven, with Indigenous people as data collectors $(26 \%$, $n=20)$ (IP1). Twenty-three percent $(n=18)$ of the reviewed initiatives were collaborative, with Indigenous people playing some role in design and execution (IP2). Only $10 \%(n=8)$ were classified as autonomous monitoring by Indigenous people with some external support (IP4) (Table 4).

Table 4. Number of initiatives within each category of participation

\begin{tabular}{lcc}
\hline \hline Category of participation & $\begin{array}{c}\text { Range of } \\
\text { weighted } \\
\text { participation } \\
\text { scores }\end{array}$ & $\begin{array}{c}\text { Number of } \\
\text { initiatives }\end{array}$ \\
\hline IP1: Externally driven with Indigenous people & $23-38$ & 20 \\
$\begin{array}{l}\text { as data collectors } \\
\begin{array}{l}\text { IP2: Collaborative with Indigenous people } \\
\text { playing some role in design and execution }\end{array}\end{array}$ & $39-53$ & 18 \\
$\begin{array}{l}\text { IP3: Collaborative with Indigenous people } \\
\text { playing a strong role in design, execution, and } \\
\text { management }\end{array}$ & $54-48$ & 31 \\
$\begin{array}{l}\text { IP4: Autonomous monitoring by Indigenous } \\
\text { people with some external support }\end{array}$ & $69-81$ & 8 \\
\hline
\end{tabular}

\section{Objectives}

Nearly all initiatives that we reviewed stated the objectives of their monitoring $(94 \%, n=72)$. Within these, we identified 19 distinct monitoring objectives (Fig. 4), with most initiatives $(62 \%, n=45)$ listing more than one objective. These objectives included resource management ( $46 \%$ of initiatives, $n=33$ ) (e.g., Constantino et al. 2012), tracking and adapting to environmental change $(35 \%, n=25)$ (e.g., Riseth et al. 2011), ensuring access to culturally important resources $(15 \%, n=11)$ (e.g., Cummings et al. 2017), biodiversity conservation $(15 \%, n=11)$ (e.g., Parry and Peres 2015), economic development $(13 \%, n=9)$ (e.g., Negi et al. 2018), monitoring impacts of industrial development $(13 \%, n=$ 
Fig. 4. Percentage of monitoring initiatives at each level of Indigenous participation, displayed according to monitoring objectives. Initiatives are classified according to the degree of participation of Indigenous people: the blue dashed line indicates externally driven initiatives with Indigenous people as data collectors (IP1); the orange dotted line indicates collaborative initiatives with Indigenous people playing some role in design and execution (IP2); the grey solid line indicates collaborative initiatives with Indigenous people playing a strong role in design, execution, and management (IP3); and the yellow dashed line indicates autonomous monitoring by Indigenous people with some external support (IP4).

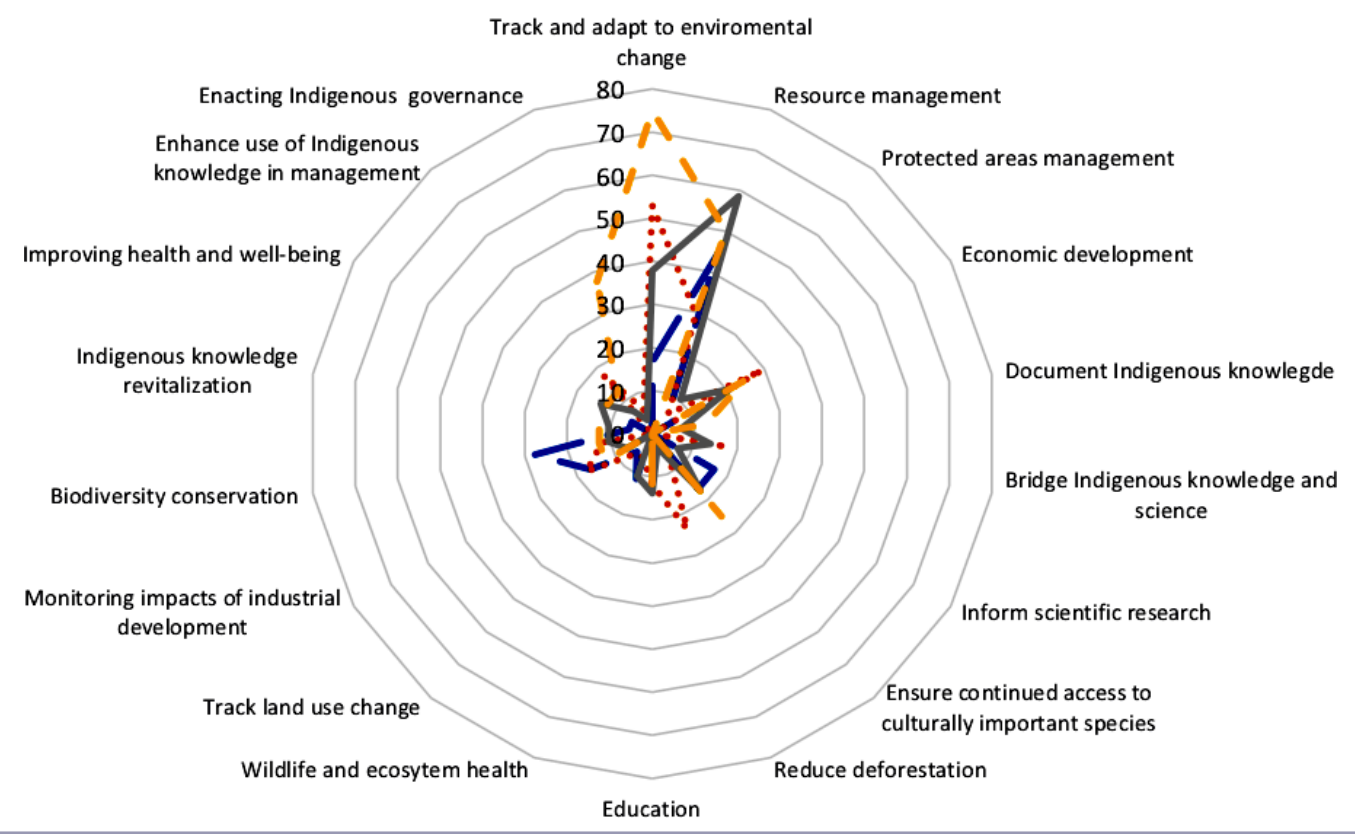

9) (e.g., McKay and Johnson 2017), bridging Indigenous knowledge and science $(8 \%, n=6)($ e.g., Lauer and Aswani 2010$)$, tracking wildlife and ecosystem health $(8 \%, n=6)($ e.g., Brook and McLachlan 2008), managing protected areas $(7 \%, n=5)(\mathrm{e}$. g., Aswani and Weiant 2004), education (7\%, $n=5)$ (e.g., Constantino et al. 2012), improving human health and well-being $(7 \%, n=5)$ (e.g., Lyver et al. 2018), enacting Indigenous governance $(7 \%, n=5)$ (e.g., Kennett et al. 2010), reducing deforestation $(6 \%, n=4)$ (e.g., Sheil et al. 2015), revitalizing Indigenous knowledge $(6 \%, n=4)$ (e.g., Morishige et al. 2018), enhancing use of Indigenous knowledge in management $(6 \%, n$ =4) (e.g., Thompson et al. 2019), informing scientific research $(4 \%, n=3)$ (e.g., Pacheco-Cobos et al. 2015), documenting Indigenous knowledge $(3 \%, n=2)$ (e.g., Danielsen et al. 2014b), and tracking land use change $(3 \%, n=3)$ (e.g., Olivero et al. 2016).

The most commonly listed objectives across all categories of participation were resource management, and tracking and adapting to environmental change. However, the frequency of objectives listed varied according to the degree of participation of Indigenous people in the monitoring initiative. One of the most striking differences was that $37 \%(n=3)$ of autonomous initiatives (IP4) indicated "enacting Indigenous governance" (e.g., Sheil et al. 2015) as a monitoring objective, as compared to $6 \%(n=1)$ of collaborative initiatives in which Indigenous people played some role in design and execution (IP2) and 3\% $(n=1)$ of collaborative initiatives in which Indigenous people played a strong role in design, execution, and management (IP3); this monitoring objective was not listed in initiatives where Indigenous peoples participated mainly as data collectors (IP1). Conversely, biodiversity conservation was mentioned as an objective of $28 \%$ $(n=5)$ of less participatory initiatives (IP1) (e.g., Parry and Peres 2015) compared to less than $15 \%$ of more participatory initiatives (IP2, IP3, and IP4).

\section{Indicators}

Eighty-six percent $(n=66)$ of the initiatives we reviewed defined the indicators they monitored. Social, ecological, and socialecological indicators were monitored in at least one initiative within each category of participation. However, the frequency of each type of indicator varied according to the participation of Indigenous people (Fig. 5). Autonomous initiatives (IP4) were most likely to monitor a diversity of indicators, with $43 \%(n=3)$ reporting that they monitored social-ecological, social, and ecological indicators within the same initiative. For example, Inuit people monitoring environmental change payed attention to ecological indicators, such as the body condition of caribou; social-ecological indicators, such as hunting success; and social indicators, such as the prevalence of knowledge about seasonal cycles in their communities (Berkes et al. 2007). Collaborative initiatives with strong Indigenous participation (IP3) were most likely to monitor a combination of ecological and socialecological indicators $(38 \%, n=11)$. For example, Kaxinawá people in collaboration with nonprofit organizations monitored wildlife in their territory using ecological indicators, such as the mean body mass and abundance of preferred harvest species, as 
Fig. 5. Percentage of monitoring initiatives at each level of Indigenous participation, displayed according to the type of indicators used. Initiatives are classified according to the degree of participation of Indigenous people: the blue dashed line indicates externally driven initiatives with Indigenous people as data collectors (IP1); the orange dotted line indicates collaborative initiatives with Indigenous people playing some role in design and execution (IP2); the grey solid line indicates collaborative initiatives with Indigenous people playing a strong role in design, execution, and management (IP3); and the yellow dashed line indicates autonomous monitoring by Indigenous people with some external support (IP4).

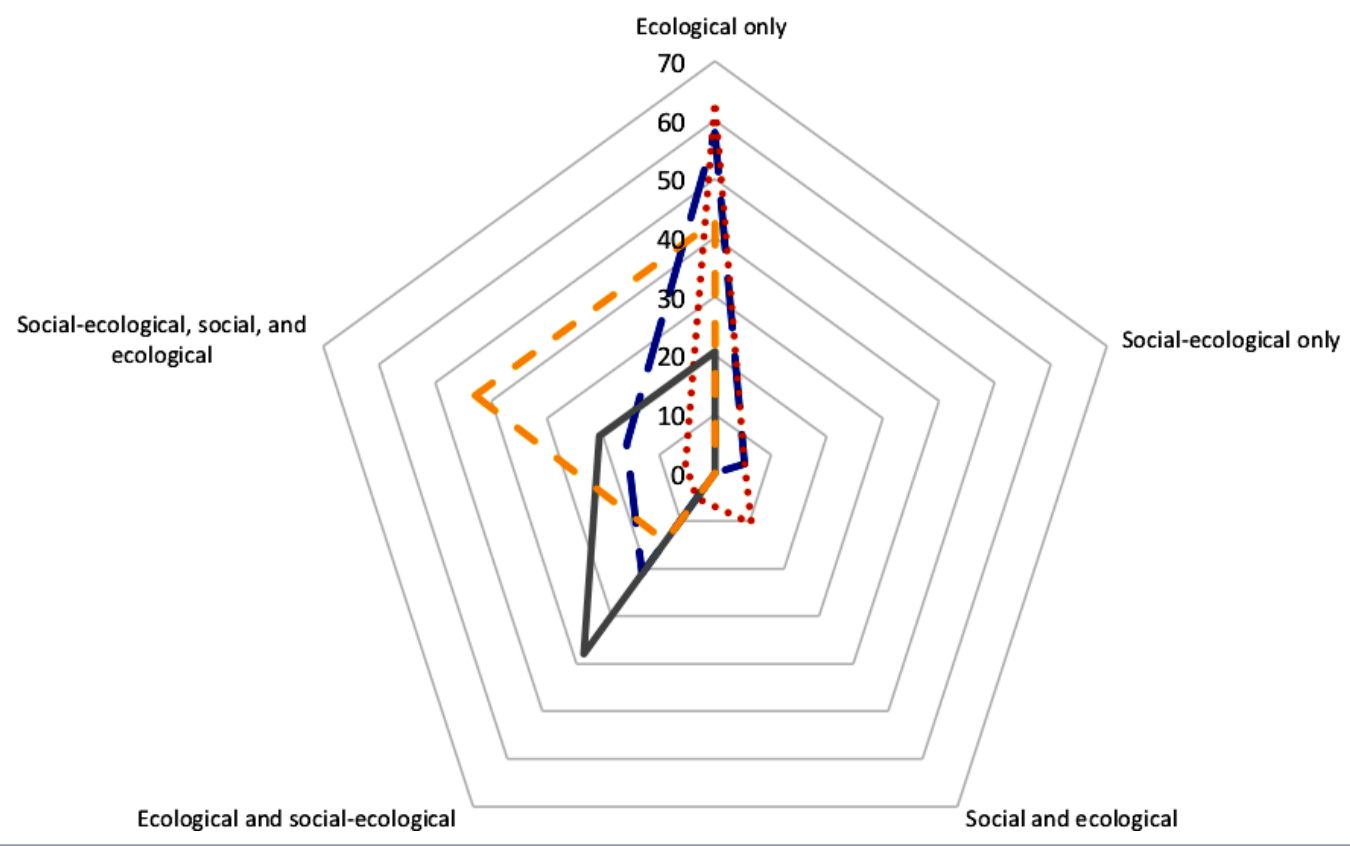

well as social-ecological indicators, such as the catch-per-unit effort of harvest species (Constantino et al. 2008). Meanwhile, initiatives with less Indigenous involvement (IP1 and IP2) were most likely to focus solely on monitoring ecological indicators $(63 \%, n=12)$. For example, Banyarwanda people were involved in monitoring the state of grazing lands by using indicators such species richness and invasive species (Oba et al. 2008).

\section{Methods}

Ninety-two percent $(n=71)$ of the initiatives we reviewed described their monitoring and data collection methods. Within these, we identified 13 distinct methods of monitoring that involved Indigenous people (Fig. 6): interviews with Indigenous people ( $45 \%$ of initiatives, $n=32$ ) (e.g., Bell and Harwood 2012); field monitoring using standard scientific methods, such as transect surveys $(42 \%, n=30)$ (e.g., Lyver et al. 2017); resourcebased activities, such as harvesting, traveling, or preparing traditional foods $(25 \%, n=18)$ (e.g., Ostertag et al. 2018); workshops or focus groups $(21 \%, n=15)$ (e.g., Grech et al. 2014); GPS trackers, including digital apps $(14 \%, n=10)$ (e.g., Gearheard et al. 2011); harvest self-reports $(14 \%, n=10)$ (e.g., Constantino et al. 2008); participatory field visits with scientific researchers $(14 \%, n=10)$ (e.g., Roba and Oba 2009); surveys or questionnaires $(11 \%, n=8)$ (e.g., Dobbs et al. 2016); participatory mapping exercises $(10 \%, n=7)$ (e.g., Setty et al. 2008); using harvested specimens for scientific analysis $(6 \%, n=4)$ (e.g., Brook and McLachlan 2008); photo, audio, or video recording of Indigenous knowledge (4\%, $n=3)$ (e.g., Gill et al. 2014); and using drones to monitor land use activities $(3 \%, n=2)$ (e.g., Olivero et al. 2016). Most initiatives $(69 \%, n=48)$ reported using more than one method. Interviews and scientific methods were the most frequently listed in all categories of participation. However, scientific field methods were used more frequently in initiatives led by external groups (IP1 and IP2: $63 \%, n=12$, and 53\%, $n=6$, respectively).

\section{Outcomes}

Within the 55 initiatives $(71 \%)$ that described outcomes of their monitoring, we identified 12 distinct outcomes (Fig. 7): management plans or actions, such as setting closures or harvest limits $(51 \%, n=27)$ (e.g., Setty et al. 2008); the suggestion that monitoring would result in future management, often because it was too soon to know whether management was needed or possible $(35 \%, n=18)$ (e.g., Torres et al. 2014); decentralizing the perceptions used for decision-making $(29 \%, n=15)$ (e.g., Danielsen et al. 2014b); empowerment of local people to participate in monitoring and management $(25 \%, n=13)$ (e.g., Gérin-Lajoie et al. 2018); local financial gain $(23 \%, n=12)$ (e.g., Bellfield et al. 2015); maintenance or revitalization of Indigenous knowledge systems $(21 \%, n=11)$ (e.g., Chambers et al. 2017); increasing local interest in science $(17 \%, n=9)$ (e.g., Brook and McLachlan 2008); increased recognition of Indigenous peoples as resource managers in broader political arenas $(15 \%, n=8)$ (e.g., Constantino et al. 2012); increasing local monitoring capacity $(10 \%, n=5)$ (e.g., 
Fig. 6. Percentage of monitoring initiatives at each level of Indigenous participation, displayed according to monitoring methods. Initiatives are classified according to the degree of participation of Indigenous people: the blue dashed line indicates externally driven initiatives with Indigenous people as data collectors (IP1); the orange dotted line indicates collaborative initiatives with Indigenous people playing some role in design and execution (IP2); the grey solid line indicates collaborative initiatives with Indigenous people playing a strong role in design, execution, and management (IP3); and the yellow dashed line indicates autonomous monitoring by Indigenous people with some external support (IP4).

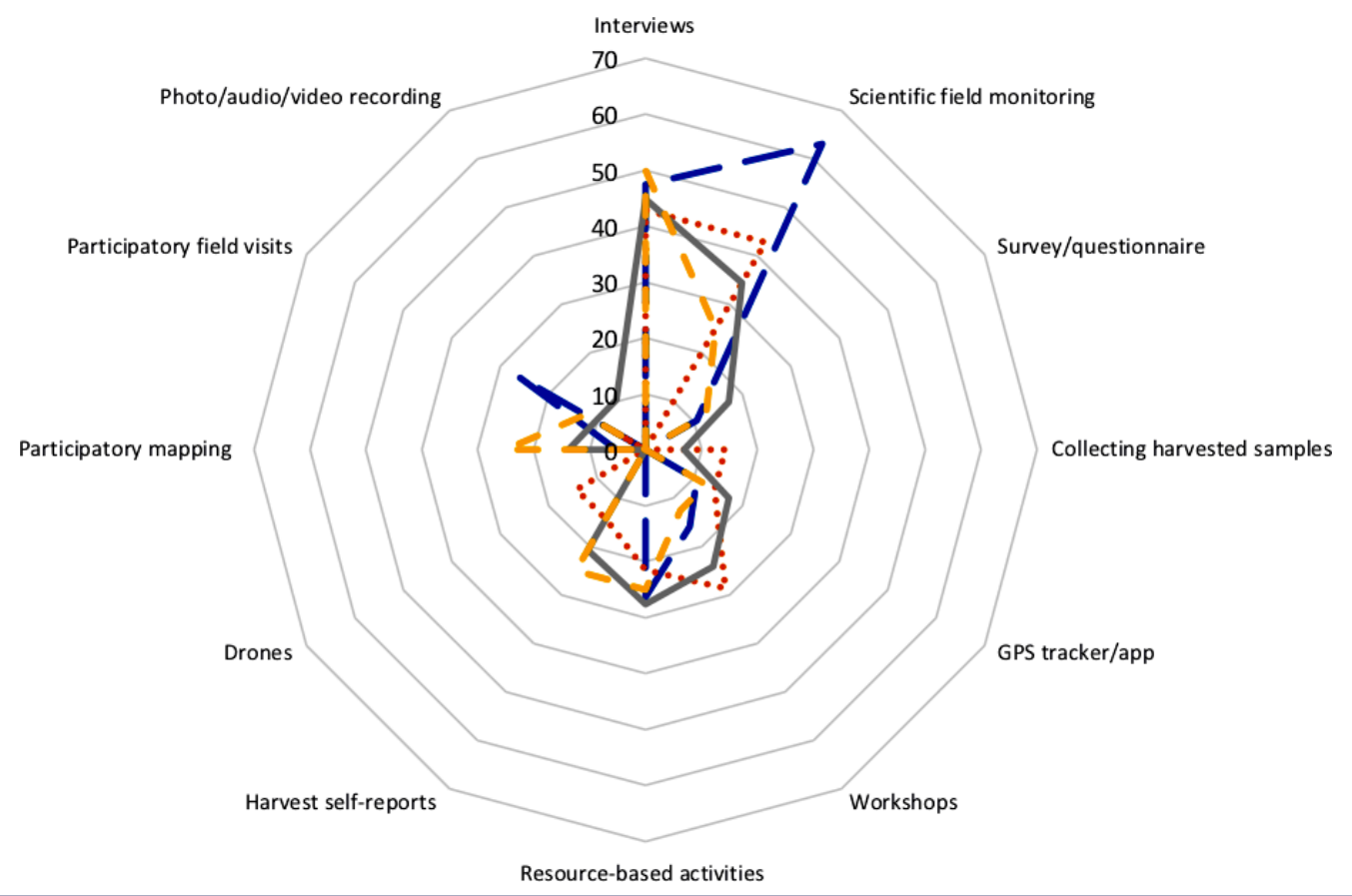

Wilson et al. 2018); increasing interest in Indigenous knowledge $(8 \%, n=4)$ (e.g., Grech et al. 2014); adding to scientific knowledge $(6 \%, n=3)$, and increased resource abundance as a result of management informed by monitoring $(2 \%, n=1)$ (Aswani and Weiant 2004).

Collaborative initiatives with strong Indigenous participation (IP3) appeared to be the most effective at enabling management outcomes $(59 \% n=16)$. For example, a marine management plan for the Yanyuwa Indigenous Protected Area was informed by the results provided by Yanyuwa families and Anthawirriyarra Sea Rangers who monitored the distribution of marine mammals alongside research scientists and government officials (Grech et al. 2014). Meanwhile, $57 \%(n=4)$ of autonomous initiatives (IP4) were set to have future management outcomes. For example, the monitoring done by Gitga'at harvesters is designed to inform ongoing stewardship plans and actions (Thompson et al. 2019). The data also suggested that collaborative initiatives (IP3) were most likely to empower Indigenous peoples to participate in monitoring and management $(37 \%, n=10)$, and to enable them to participate in broader political arenas $(22 \%, n=6)$. For example, thanks to their training and involvement in the Biodiversity and Natural Resource Use Monitoring Program of the Amazonas Protected Areas in Brazil, participating Ribeirinho people represented their communities in discussions with municipal and state governments to plan future sustainable development near the protected areas (Constantino et al. 2012).
How the literature discusses multiple knowledge systems in environmental monitoring

Nearly all the literature we reviewed contained some discussion on using science alongside Indigenous knowledge in environmental monitoring $(96 \%, n=76)$. This discussion was focused mostly on the reasons why applying both knowledge systems is beneficial ( $91 \%$ of papers discussed this theme, $n=72$ ). Meanwhile, $67 \%(n=53)$ of the papers gave examples of, or suggestions on, how to combine the knowledge systems, and 19\% $(n=24)$ delved into the challenges of attempting to do so.

The papers we reviewed mentioned many benefits of using multiple knowledge systems for monitoring. Most of these related to the complementary differences between Indigenous and scientific knowledge systems, which can add to collective understandings of the complex systems being monitored $(87 \%, n$ $=69$ ). Such complementary differences include the study of different geographic and temporal scales (e.g., Dubé et al. 2013), the reductionism of science compared to the holism of Indigenous knowledge (e.g., Prober et al. 2011), and the focus of Indigenous knowledge on extremes compared to science's ability to discern averages (e.g., Moller et al. 2004). Many papers (33\%, $n=26)$ also discussed how leveraging the work of scientists and Indigenous people can enable them to learn from one another (e.g., Fernandez-Gimenez et al. 2006), that Indigenous knowledge can help refine the methods, hypotheses, and analyses of the scientific 
Fig. 7. Percentage of monitoring initiatives at each level of Indigenous participation displayed according to monitoring outcomes. Initiatives are classified according to the degree of participation of Indigenous people: the blue dashed line indicates externally driven initiatives with Indigenous people as data collectors (IP1); the orange dotted line indicates collaborative initiatives with Indigenous people playing some role in design and execution (IP2); the grey solid line indicates collaborative initiatives with Indigenous people playing a strong role in design, execution, and management (IP3); and the yellow dashed line indicates autonomous monitoring by Indigenous people with some external support (IP4).

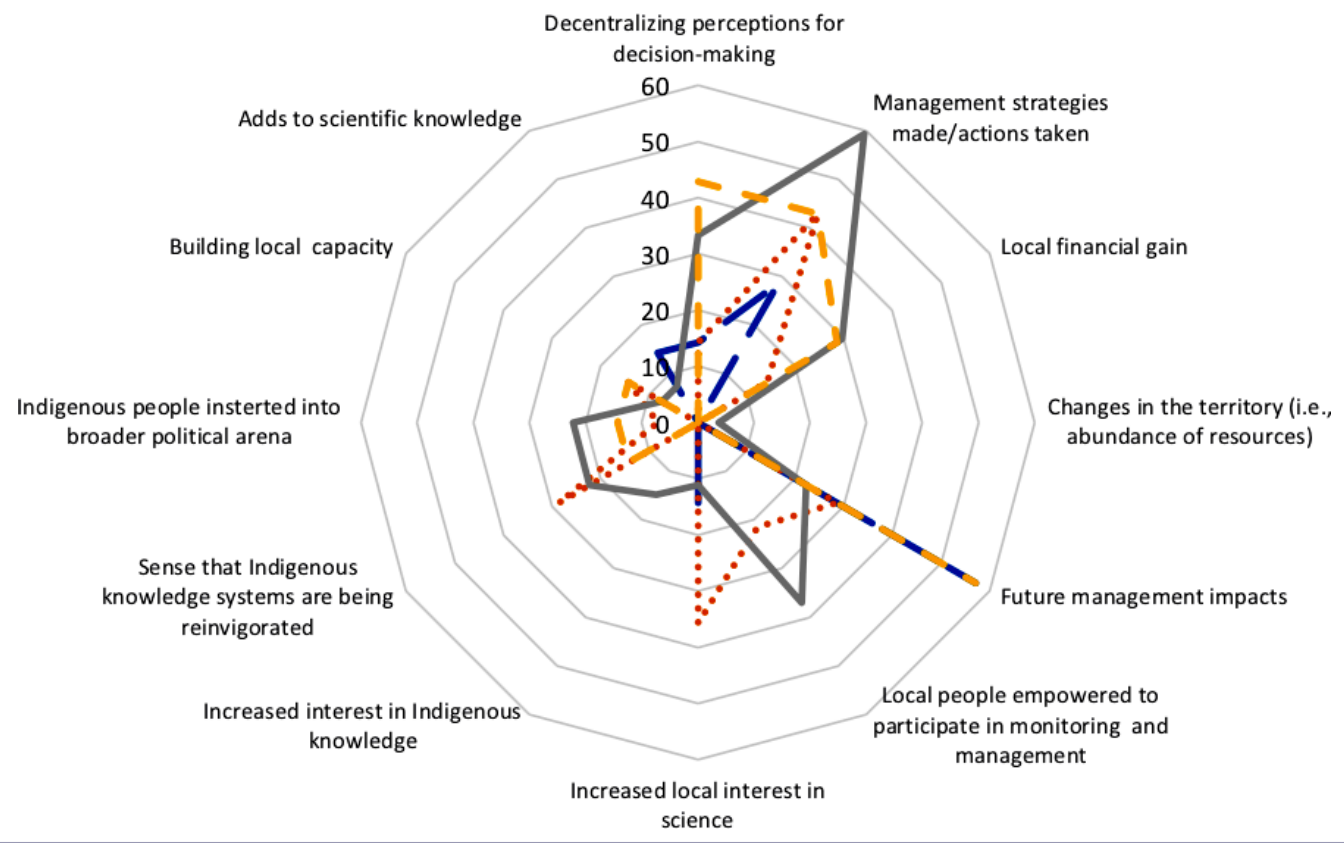

method (e.g., Gérin-Lajoie et al. 2018), that engaging local Indigenous people is often more cost-effective than hiring professional scientists (e.g., Bellfield et al. 2015), and that leveraging both science and Indigenous knowledge can make results more credible for scientists and Indigenous people (e.g., Paltsyn et al. 2019). Furthermore, about $26 \%(n=21)$ of the papers discussed having multiple knowledge systems within environmental monitoring as a means of empowering local Indigenous people by ensuring that work is geared toward furthering their objectives and values (e.g., Lyver and Lutsel K'e Dene First Nation 2005), or as a way to maintain Indigenous knowledge systems (e.g., Alessa et al. 2016).

It is also noteworthy that $24 \%(n=19)$ of the papers we reviewed brought attention to the challenges of applying diverse knowledge systems. The main challenge identified was an imbalance of power between scientists and Indigenous people $(22 \%, n=17)$. In some cases, this led to scientific knowledge being prioritized over, or displacing, Indigenous knowledge (e.g., Shrestha and Lapeyre 2018). Another paper stated that the marginalization of Indigenous people has led to their harvesting activities, which are central to the process of creating knowledge, being deemed illegal (Sheil et al. 2015). Several papers $(6 \%, n=5)$ noted that such power imbalances have led to Indigenous peoples hesitating to be open to science, and vice versa (e.g., Fernandez-Gimenez et al. 2006). Other papers discussed the challenges of negotiating conflicting findings between Indigenous knowledge and science (e.g., Roba and Oba 2008), or stressed that some information held within Indigenous knowledge may not be shareable beyond the community or family holding it because of its cultural sensitivity (e.g., Wiseman and Bardsley 2016).

Sixty-seven percent $(n=53)$ of the papers we reviewed presented approaches for leveraging Indigenous knowledge and science in monitoring. Many of them $(27 \%, n=22)$ stressed the importance of ensuring that the process of Indigenous knowledge systems be recognized to avoid removing data from its cultural context (e.g., Gill et al. 2014), and that forming relationships and spending time in shared experiences are necessary for scientists to build this understanding (e.g., Lyver et al. 2017). Numerous papers (41\%, $n=33$ ) discussed how science and scientists could support Indigenous peoples and their knowledge systems rather than replacing them by making Indigenous knowledge more accessible to people in power (e.g., Bell and Harwood 2012), by offering technical support and training in scientific methods to add to traditional methods (e.g., Cummings et al. 2017), and by helping secure funds for monitoring (e.g., Gearheard et al. 2011). It is also noteworthy that some $(18 \%, n=14)$ papers discussed inserting information produced through Indigenous knowledge systems into scientific frameworks in order to inform policy-makers who continue to privilege scientific knowledge (e.g., Olivero et al. 2016). Several papers $(16 \%, n=13)$ stated that power between scientists and Indigenous peoples needs to be equalized in order for their knowledge systems to be leveraged in a way that 
maintains each, and suggested that this could be facilitated by recognizing Indigenous authority to manage their territories (e.g., Heaslip 2008).

\section{How the literature discusses governance and power in environmental monitoring}

Fewer papers explicitly discussed the roles of governance and political power in environmental monitoring $(72 \%, n=57)$ than papers that discussed integration of knowledge systems $(96 \%, n=$ 76). Of those papers, $43 \%(n=24)$ emphasized the importance of Indigenous people having increased governance power, such as state governments recognizing traditional governance structures, in order for monitoring to be effective and have better management outcomes (e.g., Grech et al. 2014). Indeed, $17 \%$ of papers $(n=10)$ described environmental monitoring by Indigenous peoples as a demonstration of Indigenous governance and sovereignty (e.g., Dobbs et al. 2016). Fifty-seven percent $(n=29)$ of papers that discussed governance indicated that monitoring was occurring in areas where state governments were increasingly recognizing Indigenous peoples as resource managers through comanagement arrangements within lands claims agreements (e.g., Bell and Harwood 2012), and/or by recognizing their rights to harvest and manage traditional resources (e.g., Constantino et al. 2012).

Many of the papers that discussed governance $(44 \%, n=25)$ pointed to the ongoing marginalization of Indigenous people who participate in environmental monitoring. Many papers $(27 \%, n=$ 15) described how Indigenous peoples were not able to exercise management actions informed by collaborative environmental monitoring of their territories in areas where state governments did not recognize their management practices or rights, or where relationships between state governments and Indigenous peoples remained prescriptive or paternalistic (e.g., Setty et al. 2008). Twenty-three percent of papers $(n=13)$ discussed how colonialism has affected and continues to negatively impact Indigenous governance structures through mechanisms such as alienation from traditional territories, which has resulted in weakened Indigenous knowledge systems, and thus the chances of enriching monitoring efforts (e.g., Lyver et al. 2008). Furthermore, $8 \%$ of papers $(n=5)$ described how, in places where governments do not support Indigenous rights, Indigenous peoples were vulnerable to land grabs and illegal resource extraction (e.g., Paneque-Gálvez et al. 2017). A few papers $(5 \%, n=3)$ described participatory CBM as a pathway for the decolonization of academic research if enough time is allocated to build relationships and trust to overcome power imbalances (e.g., Wilson et al. 2018).

\section{Challenges and recommendations described in the literature}

Nearly all the papers we reviewed $(96 \%, n=76)$ discussed challenges and/or offered suggestions about how Indigenous peoples and their knowledge can be effectively included in environmental monitoring. The most commonly discussed challenges focused on the logistics of monitoring methods $(54 \%$, $n=41)$. Other commonly named challenges were difficulties in linking monitoring to management actions $(45 \%, n=34)$, building trust between parties $(34 \%, n=28)$, working in cross-cultural settings $(34 \%, n=26)$, maintaining community engagement $(30 \%$, $n=23)$, maintaining funding $(26 \%, n=20)$, replicating methods in time and space $(14 \%, n=11)$, and managing data $(18 \%, n=14)$.

Though many challenges were named, the literature also offered recommendations for addressing them (Table 5). An additional noteworthy challenge that was mentioned but not addressed in the literature was the concerns of some Indigenous monitors about threats of violence they had received while monitoring their territories (Sheil et al. 2015, Paneque-Gálvez et al. 2017).

\section{DISCUSSION}

Our literature search confirms that there is increasing academic interest in Indigenous people's involvement in environmental monitoring. The literature notes that a diversity of Indigenous peoples have participated in monitoring diverse ecosystems worldwide. However, our analysis indicates that many papers did not describe how Indigenous people participate in the different phases of environmental monitoring. Our findings are similar to those of Turreira-García et al. (2018), who demonstrated that the literature on participatory environmental monitoring most often writes about participation as data collection, while it is less clear how local people participate in initiating projects, setting objectives, designing methods, and ultimately making management decisions based on information gained through monitoring. It is critical to examine and describe details of participatory monitoring initiatives, including who benefits from monitoring; otherwise, there is a risk of perpetuating projects that tokenize or coerce Indigenous communities rather than enabling transformation through the sharing of power (Arnstein 1969, Cornwall 2008). This is especially important in order to promote the accountability of organizations and governments that have committed to reconciliation with Indigenous peoples through collaborative resource management approaches (e.g., Government of Canada 2018, Government of British Columbia 2019).

Our analysis of the participation that was described in the literature demonstrates that the degree of participation by Indigenous peoples influences the objective of environmental monitoring, which indicators are used, and the monitoring of outcomes. Although monitoring to inform adaptation to environmental change and resource management were objectives commonly listed by initiatives across the spectrum of participation, monitoring that was led by Indigenous people(IP4) placed additional emphasis on enacting Indigenous governance and ensuring continued access to culturally important resources. Further, Indigenous-led monitoring was more likely to take a combination of social, ecological, and social-ecological indicators into account. We encourage the use of this approach, given that monitoring both social and ecological indicators can provide a better understanding of complex social-ecological systems and enable adaptive management (Ostrom 2009, Folke et al. 2010, Caillon et al. 2017, Sterling et al. 2017).

Our results also show that autonomous monitoring initiatives (IP4) were less frequently reported as having management outcomes than those with higher degrees of outside influence (IP3, IP4). There are several possible explanations for this. First, if the rights of Indigenous people to manage their territories are not recognized more broadly, autonomous monitoring initiatives may not be linked to the governments that have the authority to enable or deny management actions (Wiseman and Bardsley 2016). Monitoring partnerships with agencies that have strong ties to state management authorities (i.e., universities, NGOs, comanagement boards) may be more likely to be taken into account by those in power. Such partnerships can help leverage Indigenous concerns and methods, but they must be designed to 
Table 5. Challenges and associated recommendations discussed in the literature reviewed

\begin{tabular}{|c|c|c|}
\hline Aspect of monitoring & Challenges & Recommendations \\
\hline \multirow[t]{6}{*}{ Logistics } & $\begin{array}{l}\text { Local people may have limited time to partake in monitoring } \\
\text { due to other community obligations (e.g., Aswani and } \\
\text { Weiant 2004) }\end{array}$ & $\begin{array}{l}\text { Build on and support pre-existing or traditional systems of } \\
\text { monitoring (e.g., Wiseman and Bardsley 2016) }\end{array}$ \\
\hline & & $\begin{array}{l}\text { Factor in community events and obligations when designing } \\
\text { monitoring initiatives (e.g., Gérin-Lajoie et al. 2018) }\end{array}$ \\
\hline & $\begin{array}{l}\text { Local people may be experiencing research fatigue due to } \\
\text { other projects (e.g., Setty et al. 2008) }\end{array}$ & $\begin{array}{l}\text { Keep monitoring objectives relevant to local concerns (e.g., Eamer } \\
\text { 2006) }\end{array}$ \\
\hline & $\begin{array}{l}\text { Some technologies may be difficult to operate or maintain in } \\
\text { remote communities (i.e., due to harsh weather conditions or } \\
\text { limited internet connectivity) (e.g., Brammer et al. 2016) }\end{array}$ & $\begin{array}{l}\text { Aim for low-cost and simple methods (e.g., Garcia and Lescuyer } \\
\text { 2008) }\end{array}$ \\
\hline & & Be ready to be flexible and adaptable (e.g., Brammer et al. 2016) \\
\hline & $\begin{array}{l}\text { Harvest-based studies often incur nonrandom sampling } \\
\text { because preferred harvest may be biased toward certain body } \\
\text { conditions, and may reflect a specific space and time (e.g., } \\
\text { Bell and Harwood 2012) }\end{array}$ & $\begin{array}{l}\text { Use multiple methods (e.g., Lyver and Lutsël K'e Dene First Nation } \\
\text { 2005) }\end{array}$ \\
\hline \multirow[t]{5}{*}{$\begin{array}{l}\text { Working in cross-cultural } \\
\text { settings }\end{array}$} & $\begin{array}{l}\text { There may be mismatches between local and larger scale (i.e., } \\
\text { national or global) objectives and indicators (e.g., Lam et al. } \\
\text { 2019) }\end{array}$ & $\begin{array}{l}\text { Review tensions and disagreements openly and frequently (e.g., Stori } \\
\text { et al. 2019) }\end{array}$ \\
\hline & & Parties should be prepared to be versatile (e.g., Bellfield et al. 2015) \\
\hline & $\begin{array}{l}\text { Difficulties translating scientific and Indigenous } \\
\text { terminologies and worldviews (e.g.. Nichols et al. 2004) }\end{array}$ & $\begin{array}{l}\text { Train scientists and resource managers in participatory and cross- } \\
\text { cultural approaches (e.g., Dobbs et al. 2016) }\end{array}$ \\
\hline & & $\begin{array}{l}\text { Build in mechanisms for bidirectional capacity building (e.g., Kaiser } \\
\text { et al. 2019) }\end{array}$ \\
\hline & & $\begin{array}{l}\text { Include individuals with dual scientific and Indigenous knowledge } \\
\text { competence in all phases of design, implementation, and analysis (e. } \\
\text { g., Riseth et al. 2011) }\end{array}$ \\
\hline \multirow[t]{2}{*}{ Informing management } & $\begin{array}{l}\text { Challenge informing change when management authority is } \\
\text { uncoupled from monitoring (e.g., Wiseman and Bardsley } \\
\text { 2016) }\end{array}$ & $\begin{array}{l}\text { Decentralize management authority and recognize management } \\
\text { rights of Indigenous peoples (e.g., Wilson et al. 2018) }\end{array}$ \\
\hline & & $\begin{array}{l}\text { Include holders of Indigenous knowledge as decision-makers (e.g., } \\
\text { Lyver et al. 2017) }\end{array}$ \\
\hline \multirow[t]{4}{*}{$\begin{array}{l}\text { Building trust between } \\
\text { parties }\end{array}$} & $\begin{array}{l}\text { Indigenous peoples may fear that monitoring data will be } \\
\text { used against them due to historical and contemporary power } \\
\text { imbalances and breaches of trust (e.g., McKay and Johnson } \\
\text { 2017) }\end{array}$ & $\begin{array}{l}\text { Invest the time necessary to build relationships, including shared } \\
\text { activities and feedback (e.g., Wilson et al. 2018) }\end{array}$ \\
\hline & & Enable local leadership (e.g., Brook et al. 2009) \\
\hline & & $\begin{array}{l}\text { Establish research protocol agreements and define roles, } \\
\text { responsibilities, and expectations early on (e.g., Morishige et al. 2018) }\end{array}$ \\
\hline & & $\begin{array}{l}\text { Communicate results frequently and seek feedback. Ensure that } \\
\text { information is accessible to participating communities (e.g., Ostertag } \\
\text { et al. 2018) }\end{array}$ \\
\hline \multirow[t]{4}{*}{$\begin{array}{l}\text { Maintaining community } \\
\text { engagement }\end{array}$} & $\begin{array}{l}\text { Can be difficult to keep monitors and participants engaged } \\
\text { over long periods of time (e.g., Brook and McLachlan 2008) }\end{array}$ & $\begin{array}{l}\text { Ensure that monitors and participants are fairly compensated (e.g., } \\
\text { Bellfield et al. 2015) }\end{array}$ \\
\hline & & $\begin{array}{l}\text { Build in opportunities for training and education (e.g., Constantino } \\
\text { et al. 2012) }\end{array}$ \\
\hline & & Engage youth (e.g., Bell and Harwood 2012) \\
\hline & & $\begin{array}{l}\text { Ensure that there are tangible benefits to monitoring, and } \\
\text { communicate them regularly (e.g., Danielsen et al. 2014b) }\end{array}$ \\
\hline Funding & $\begin{array}{l}\text { Can be a challenge to maintain long-term funding necessary } \\
\text { to sustain monitoring programs (e.g., Danielsen et al. 2014b) }\end{array}$ & $\begin{array}{l}\text { Secure institutional (i.e., governmental) commitments to continuous } \\
\text { funding (e.g., Bellfield et al., 2015) }\end{array}$ \\
\hline \multirow[t]{2}{*}{ Replicability } & $\begin{array}{l}\text { Difficulty maintaining consistency in monitoring methods } \\
\text { over time and over larger scales (e.g., Wiseman and Bardsley } \\
\text { 2016) }\end{array}$ & Digital data entry can reduce error (e.g., Brammer et al. 2016) \\
\hline & & $\begin{array}{l}\text { Build networks with other community-based monitoring initiatives to } \\
\text { standardize protocols (e.g., Gérin-Lajoie et al. 2018) }\end{array}$ \\
\hline \multirow[t]{2}{*}{ Data management } & $\begin{array}{l}\text { Some data are culturally sensitive and not intended for larger } \\
\text { audiences (e.g., Alessa et al. 2016) }\end{array}$ & $\begin{array}{l}\text { Define data ownership and intellectual property early on (e.g., } \\
\text { Chambers et al. 2017) }\end{array}$ \\
\hline & $\begin{array}{l}\text { Challenge documenting and storing data without } \\
\text { uncoupling from practice and belief systems (e.g., Pulsifer et } \\
\text { al. 2012) }\end{array}$ & $\begin{array}{l}\text { During initiative design phase, allow for enough time to build and } \\
\text { test the suitability of data management systems (e.g., Pulsifer et al. } \\
\text { 2012) }\end{array}$ \\
\hline
\end{tabular}

ensure that Indigenous peoples are central in management discussions (in order to ensure that science and Indigenous knowledge are equally considered [e.g., Housty et al. 2014, Atlas et al. 2017]).
Another possible explanation for our finding may be that the autonomous management actions by Indigenous peoples that have been informed by monitoring have been poorly documented in the monitoring-related literature published to date. The positive 
outcomes of Indigenous territorial management, including more biodiversity on Indigenous lands (Schuster et al. 2019, Fa et al. 2020), enhanced and sustainable productivity of resources, such as intertidal resources (Groesbeck et al. 2014, Jackley et al. 2016), salmon (Trosper 2002, Langdon 2006), and plants (Turner and Deur 2013), is becoming increasingly recognized in the ethnoecological literature. Evidencing the links between these management outcomes and monitoring by Indigenous peoples, which centers on continued access to, and utilization of, these resources, could help ensure broader support of Indigenous participation and leadership in environmental monitoring.

Our review also indicates that there is a strong interest in leveraging both scientific and Indigenous knowledge systems in environmental monitoring, and that many synergies can be drawn between both to enhance the information gained through monitoring. However, there remain key systemic challenges, namely the privileging of the monitoring methods and knowledge of scientists above those of Indigenous experts (e.g., Shaffer 2014, Wiseman and Bardsley 2016). Given that power plays such a central role in navigating participation and leveraging Indigenous knowledge in monitoring, we recommend that future initiatives and publications to factor in issues of power and governance when designing and reporting on collaborative environmental monitoring projects. Our review suggests that, beyond encouraging governance arrangements that more closely link Indigenous monitoring to management, considering the sharing of power in monitoring initiatives early and often is essential to ensure that objectives, indicators, and methods are embedded in the values of Indigenous communities and appropriately engage Indigenous knowledge. In turn, local relevance and tangible monitoring outcomes are more likely to encourage continued monitoring efforts by all parties involved.

We recognize that we may have omitted some relevant literature because our search was conducted in English only and within a single database. Further, this review may not reflect the entirety of Indigenous participation in environmental monitoring, given that much autonomous monitoring by Indigenous peoples may not be documented in the academic literature. It is also important to consider that many of the articles reviewed may not reflect the perspective of Indigenous community members. This is also true of our paper, and we encourage the academic community to pay attention to the works of Indigenous scholars' commentary on these issues. Finally, though participation exists on a spectrum, we have attempted to classify degrees of participation into discrete categories for analytical purposes and thus have not highlighted the nuances of each initiative reviewed. Despite these limitations, we believe that our review contributes to the ongoing discussion and can provide insights to groups seeking to develop monitoring initiatives, which are becoming increasingly relevant in a time of rapid social and ecological change.

\section{CONCLUSION}

Our literature review demonstrates that Indigenous peoples and their knowledge have been engaged in environmental monitoring through a variety of participatory arrangements. The degree of participation and power held by Indigenous peoples throughout the process of monitoring from initiating projects to implementing management influences the objectives, methods, indicators, and outcomes. The benefits are optimized when power is shared between scientists and Indigenous experts, and when the rights of Indigenous peoples as managers of their territories are recognized and enabled by other governments. Parties interested in creating environmental monitoring initiatives in partnership with Indigenous peoples must closely examine the details of participation, power, and governance in order to create programs that are socially just and effective for monitoring various aspects of complex social-ecological systems, including but not limited to impacts of industrial development and climate change.

Responses to this article can be read online at: http://www.ecologyandsociety.org/issues/responses. php/11503

\section{Acknowledgments:}

KLT and NCB were supported by a Social Sciences and Humanities Research Council of Canada Insight grant, Natural Sciences and Engineering Research Council Discovery grant, and the University of Victoria. KLT was also supported by the Elizabeth Henry Scholarship for Communities and Environmental Health, and the Jacobs Research Funds. Thanks to Nancy Turner for her helpful suggestions in the development of this manuscript. KLT and NCB would also like to thank the Marine Ethnoecology Research group at the University of Victoria for methodological advice. KLT is grateful to knowledge holders, stewards, and leaders of the Gitga'at Nation for inviting her to participate in monitoring their traditional territory and for inspiring this work. We would also like to thank the anonymous reviewers for their helpful suggestions, which greatly improved this manuscript. The authors have no competing interests to declare.

\section{Data Availability Statement:}

Datalcode sharing is not applicable to this article because no new datalcode were created or analyzed in this study.

\section{LITERATURE CITED}

Alessa, L., A. Kliskey, J. Gamble, M. Fidel, G, Beaujean, and J. Gosz. 2016. The role of Indigenous science and local knowledge in integrated observing systems: moving toward adaptive capacity indices and early warning systems. Sustainability Science 11:91-102. https://doi.org/10.1007/s11625-015-0295-7

Arnstein, S. R. 1969. A ladder of citizen participation. Journal of the American Institute of Planners 35(4):216-224. https://doi. org/10.1080/01944366908977225

Aswani, S., and P. Weiant. 2004. Scientific evaluation in women's participatory management: monitoring marine invertebrate refugia in the Solomon Islands. Human Organization 63 (3):301-319. https://doi.org/10.17730/humo.63.3.r7kgd4thktmyf7k1

Atlas, W. I., W. G. Housty, A. Béliveau, B. DeRoy, G. Callegari, M. Reid, and J. W. Moore. 2017. Ancient fish weir technology for modern stewardship: lessons from community-based salmon monitoring. Ecosystem Health and Sustainability 3(6). https://doi. org/10.1080/20964129.2017.1341284 
Ban, N. C., A. Frid, M. Reid, B. Edgar, D. Shaw, and P. Siwallace. 2018. Incorporate Indigenous perspectives for impactful research and effective management. Nature Ecology \& Evolution 2 (11):1680-1683. https://doi.org/10.1038/s41559-018-0706-0

Bell, R. K., and L. A. Harwood. 2012. Harvest-based monitoring in the Inuvialuit Settlement Region: steps for success. Arctic 65 (4):421-432. https://doi.org/10.14430/arctic4240

Bellfield, H., D. Sabogal, L. Goodman, and M. Leggett. 2015. Case study report: community-based monitoring systems for REDD+ in Guyana. Forests 6(1):133-156. https://doi. org/10.3390/f6010133

Berkes, F. 2012. Sacred ecology. Third edition. Routledge. https:// doi.org/10.4324/9780203123843

Berkes, F., M. K. Berkes, and H. Fast. 2007. Collaborative integrated management in Canada's north: the role of local and traditional knowledge and community-based monitoring. Coastal Management 35(1):143-162. https://doi.org/10.1080/08920750600970487

Berkes, F., J. Colding, and C. Folke. 2000. Rediscovery of traditional ecological knowledge as adaptive management. Ecological Applications 10(5):1251-1262. https://doi.org/10.1890/1051-0761 (2000)010[1251:ROTEKA]2.0.CO;2

Bohensky, E. L., and Y. Maru. 2011. Indigenous knowledge, science, and resilience: What have we learned from a decade of international literature on "integration"? Ecology and Society 16 (4):6. http://dx.doi.org/10.5751/ES-04342-160406

Brammer, J. R., N. D. Brunet, A. C. Burton, A. Cuerrier, F. Danielsen, K. Dewan, T. M. Herrmann, M. V. Jackson, R. Kennett, G. Larocque, M. Mulrennan, A. K. Pratihast, M. SaintArnaud, C. Scott, and M. M. Humphries. 2016. The role of digital data entry in participatory environmental monitoring. Conservation Biology 30(6):1277-1287. https://doi.org/10.1111/ cobi. 12727

Brook, R. K., S. J. Kutz, A. M. Veitch, R. A. Popko, B. T. Elkin, and G. Guthrie. 2009. Fostering community-based wildlife health monitoring and research in the Canadian north. EcoHealth 6:266-278. https://doi.org/10.1007/s10393-009-0256-7

Brook, R. K., and S. M. McLachlan. 2008. Trends and prospects for local knowledge in ecological and conservation research and monitoring. Biodiversity and Conservation 17(14):3501-3512. https://doi.org/10.1007/s10531-008-9445-x

Caillon, S., G. Cullman, B. Verschuuren, and E. J. Sterling. 2017. Moving beyond the human-nature dichotomy through bicultural approaches: including ecological well-being in resilience indicators. Ecology and Society 22(4):27. https://doi.org/10.5751/ ES-09746-220427

Chambers, L. E., R. D. Plotz, T. Dossis, D. H. Hiriasia, P. Malsale, D. J. Martin, R. Mitiepo, K. Tahera, and T. I. Tofaeono. 2017. A database for traditional knowledge of weather and climate in the Pacific. Meteorological Applications 24(3):491-502. https://doi. org/10.1002/met.1648

Constantino, P. de A. L., H. S. A. Carlos, E. E. Ramalho, L. Rostant, C. E. Marinelli, D. Teles, S. F. Fonseca-Junior, R. B. Fernandes, and J. Valsecchi. 2012. Empowering local people through community-based resource monitoring: a comparison of Brazil and Namibia. Ecology and Society 17(4):22. http://dx. doi.org/10.5751/ES-05164-170422

Constantino, P., L. B. Fortini, F. R. S. Kaxinawa, A. M. Kaxinawa, E. S. Kaxinawa, A. P. Kaxinawa, L. S. Kaxinawa, J. M. Kaxinawa, and J. P. Kaxinawa. 2008. Indigenous collaborative research for wildlife management in Amazonia: the case of the Kaxinawá, Acre, Brazil. Biological Conservation 141(11):2718-2729. https:// doi.org/10.1016/j.biocon.2008.08.008

Corntassel, J. J. 2003. Who is indigenous? "Peoplehood" and ethnonationalist approaches to rearticulating Indigenous identity. Nationalism and Ethnic Politics 9(1):75-100. https://doi. org/10.1080/13537110412331301365

Cornwall, A. 2008. Unpacking 'participation' models, meanings and practices. Community Development Journal 43(3):269-283. https://doi.org/10.1093/cdj/bsn010

Cummings, A. R., G. R. Cummings, E. Hamer, P. Moses, Z. Norman, V. Captain, R. Bento, and K. Butler. 2017. Developing a UAV-based monitoring program with Indigenous peoples. Journal of Unmanned Vehicle Systems 5(4):115-125. https://doi. org/10.1139/juvs-2016-0022

Danielsen, F., N. D. Burgess, A. Balmford, P. F. Donald, M. Funder, J. P. G. Jones, P. Alviola, D. S. Balete, T. Blomley, J. Brashares, B. Child, M. Enghoff, J. Fjeldså, S. Holt, H. Hübertz, A. E. Jensen, P. M. Jensen, J. Massao, M. M. Mendoza, Y. Ngaga, M. K. Poulsen, R. Rueda, M. Sam, T. Skielboe, G. Stuart-Hill, E. Topp-Jørgensen, and D. Yonten. 2009. Local participation in natural resource monitoring: a characterization of approaches. Conservation Biology 23(1):31-42. https://doi.org/10.1111/ j.1523-1739.2008.01063.x

Danielsen, F., A. E. Jensen, P. A. Alviola, D. S. Balete, M. Mendoza, A. Tagtag, C. Custodio, and M. Enghoff. 2005. Does monitoring matter? A quantitative assessment of management decisions from locally-based monitoring of protected areas. Biodiversity \& Conservation 14:2633-2652. https://doi.org/10.1007/ $\underline{\mathrm{s} 10531-005-8392-\mathrm{Z}}$

Danielsen, F., K. Pirhofer-Walzl, T. P. Adrian, D. R. Kapijimpanga, N. D. Burgess, P. Jensen, M., R. Bonney, M. Funder, A. Landa, N. Levermann, and J. Madsen. 2014a. Linking public participation in scientific research to the indicators and needs of international environmental agreements. Conservation Letters 7(1):12-24. https://doi.org/10.1111/conl.12024

Danielsen, F., E. Topp-Jørgensen, N. Levermann, and P. Løvstrøm. 2014b. Counting what counts: using local knowledge to improve Arctic resource management. Polar Geography 37 (1):69-91. https://doi.org/10.1080/1088937X.2014.890960

Davis, A., and K. Ruddle. 2015. Constructing confidence rational skepticism and systematic enquiry in local ecological knowledge. Ecological Applications 20(3):880-894. https://doi.org/10.1890/09-0422.1

Dhillon, J. K. 2015. Indigenous girls and the violence of settler colonial policing. Decolonization: Indigeneity, Education and Society 4(2):1-31.

Dobbs, R. J., C. L. Davies, M. L. Walker, N. E. Pettit, B. J. Pusey, P. G. Close, Y. Akune, N. Walsham, B. Smith, A. Wiggan, P. Cox, 
D. P. Ward, F. Tingle, R. Kennett, M. V, Jackson, and P. M. Davies. 2016. Collaborative research partnerships inform monitoring and management of aquatic ecosystems by Indigenous rangers. Reviews in Fish Biology and Fisheries 26:711-725. https://doi. org/10.1007/s11160-015-9401-2

Dubé, M. G., J. E. Wilson, and J. Waterhouse. 2013. Accumulated state assessment of the Yukon River watershed: Part II quantitative effects-based analysis integrating western science and traditional ecological knowledge. Integrated Environmental Assessment and Management 9(3):439-455. https://doi.org/10.1002/ ieam.1363

Eamer, J. 2006. Keep it simple and be relevant: the first ten years of the Arctic Borderlands Ecological Knowledge Co-op. Bridging Scales and Knowledge Systems May 2011:185-206.

Eckert, L. E., N. C. Ban, A. Frid, and M. Mcgreer. 2017. Diving back in time: extending historical baselines for yelloweye rockfish with Indigenous knowledge. Aquatic Conservation: Marine and Freshwater Ecosystems 28(1):158-166. https://doi.org/10.1002/ aqc. 2834

Ens, E. J., P. Cooke, R. Nadjamerrek, S. Namundja, V. Garlngarr, and D.Yibarbuk. 2010. Combining Aboriginal and nonAboriginal knowledge to assess and manage feral water buffalo impacts on perennial freshwater springs of the Aboriginal-owned Arnhem Plateau, Australia. Environmental Management 45:751-758. https://doi.org/10.1007/s00267-010-9452-Z

Fa, J. E., J. E. Watson, I. Leiper, P. Potapov, T. D. Evans, N. D. Burgess, Z. Molnár, Á. Fernández-Llamazares, T. Duncan, S. Wang, B. J. Austin, H. Jonas, C. J. Robinson, P. Malmer, K. K. Zander, M. V. Jackson, E. Ellis, E. S. Brondizio, and S. T. Garnett. 2020. Importance of Indigenous peoples' lands for the conservation of intact forest landscapes. Frontiers in Ecology and the Environment 1-6. https://doi.org/10.1002/fee.2148

Fereday, J., and E. Muir-Cochrane. 2006. Demonstrating rigor using thematic analysis: a bybrid approach of inductive and deductive coding and theme development. International Journal of Qualitative Methods 5(1):80-92. https://doi.org/10.1177/1609$\underline{40690600500107}$

Fernandez-Gimenez, M. E., H. P. Huntington, and K. J. Frost. 2006. Integration or co-optation? Traditional knowledge and science in the Alaska Beluga Whale Committee. Environmental Conservation 33(4):306-315. https://doi.org/10.1017/S0376892906003420

Fisheries and Oceans Canada. 2020. 2020/21 Crab Integrated FIsheries Management Plan. https://www.pac.dfo-mpo.gc.ca/fmgp/mplans/crab-crabe-ifmp-pgip-sm-eng.pdf

Folke, C. 2006. Resilience: the emergence of a perspective for social-ecological systems analyses. Global Environmental Change 16(3):253-267. https://doi.org/10.1016/j.gloenvcha.2006.04.002

Folke, C., S. R. Carpenter, B. Walker, M. Scheffer, T. Chappin, and J. Rockström. 2010. Resilience thinking: integrating resilience, adaptability and transformability. Ecology and Society 15(4):20. https://doi.org/10.5751/ES-03610-150420

Frid, A., M. McGreer, and A. Stevenson. 2016. Rapid recovery of Dungeness crab within spatial fishery closures declared under indigenous law in British Columbia. Global Ecology and Conservation 6:48-57. https://doi.org/10.1016/j.gecco.2016.01.002
Gadgil, M., P. R. S. Rao, P. Pramod, A. Chhatre, and G. Utkarsh. 2000. New meanings for old knowledge: the People's Biodiversity Registers program. Ecological Applications 10(5):1307-1317. https://doi.org/10.2307/2641286

Garcia, C. A., and G. Lescuyer. 2008. Monitoring, indicators and community based forest management in the tropics: pretexts or red herrings? Biodiversity and Conservation 17:1303-1317. https:// doi.org/10.1007/s10531-008-9347-y

Gearheard, S., C. Aporta, G. Aipellee, and K. O'Keefe. 2011. The Igliniit project: Inuit hunters document life on the trail to map and monitor arctic change. Canadian Geographer 55(1):42-55. https://doi.org/10.1111/j.1541-0064.2010.00344.x

Gérin-Lajoie, J., T. M. Herrmann, G. A. MacMillan, É. HébertHoule, M. Monfette, J. A. Rowell, T. A. Soucie, H. Snowball, E. Townley, E. Lévesque, M. Amyot, J. Franssen, and J. P. Dedieu. 2018. IMALIRIJIIT: a community-based environmental monitoring program in the George River watershed, Nunavik, Canada. Écoscience 25(4):381-399. https://doi.org/10.1080/1195$\underline{6860.2018 .1498226}$

Gill, H., T. Lantz, and the Gwich'in Social Cultural Institute. 2014. A community-based approach to mapping Gwich'in observations of environmental changes in the lower Peel River watershed, NT. Journal of Ethnobiology 34(3):294-314. https:// doi.org/10.2993/0278-0771-34.3.294

Government of British Columbia. 2019. B. C. Declaration on the Rights of Indigenous Peoples Act. https://www2.gov.bc.ca/gov/ content/governments/indigenous-people/new-relationship/unitednations-declaration-on-the-rights-of-indigenous-peoples

Government of Canada. 2018. Principles respecting the Government of Canada's relationship with Indigenous peoples. https://www.justice.gc.ca/eng/csj-sjc/principles-principes.html

Gratani, M., J. R. A. Butler, F. Royee, P. Valentine, D. Burrows, W. I. Canendo, and A. S. Anderson. 2011. Is validation of Indigenous ecological knowledge a disrespectful process? A case study of traditional fishing poisons and invasive fish management from the wet tropics, Australia. Ecology and Society 16(3):16. https://doi.org/10.5751/ES-04249-160325

Grech, A., G. J. Parra, I. Beasly, J. Bradley, S. Johnson, S. Whiting, li-Anthawirriyarra Sea Rangers, Yanyuwa Families, and $\mathrm{H}$. Marsh. 2014. Local assessments of marine mammals in crosscultural environments. Biodiversity and Conservation 23:3319-3338. https://doi.org/10.1007/s10531-014-0783-6

Greening, S. 2017. Raven bloodlines, Tsimshian identity: an autoethnographic account of Tsimshian Wil'naat'al, politics, pedagogy, and law. Thesis. University of Northern British Columbia, Prince George, B.C., Canada.

Groesbeck, A. S., K. Rowell, D. Lepofsky, and A. K. Salomon. 2014. Ancient clam gardens increased shellfish production: adaptive strategies from the past can inform food security today. PLoS ONE 9(3). https://doi.org/10.1371/journal.pone.0091235

Heaslip, R. 2008. Monitoring salmon aquaculture waste: the contribution of First Nations' rights, knowledge, and practices in British Columbia, Canada. Marine Policy 32(6):988-996. https:// doi.org/10.1016/j.marpol.2008.02.002 
Housty, W. G., A. Noson, G. W. Scoville, J. Boulanger, R. M. Jeo, C. T. Darimont, and C. E. Filardi. 2014. Grizzly bear monitoring by the Heiltsuk people as a crucible for First Nation conservation practice. Ecology and Society 19(2):70. https://doi.org/10.5751/ ES-06668-190270

Hsieh, H. F., and S. E. Shannon. 2005. Three approaches to qualitative content analysis. Qualitative Health Research 15 (9):1277-1288. https://doi.org/10.1177/1049732305276687

Huntington, H. P. 2000. Using traditional ecological knowledge in science: methods and applications. Ecological Applications 10 (5):1270-1274. https://doi.org/10.1890/1051-0761(2000)010[1270: UTEKIS]2.0.CO;2

Jackley, J., L. Gardner, A. F. Djunaedi, and A. K. Salomon. 2016. Ancient clam gardens, traditional management portfolios, and the resilience of coupled human-ocean systems. Ecology and Society 21(4):20. https://doi.org/10.5751/ES-08747-210420

Janssen, M. A., J. M. Anderies, and E. Ostrom. 2007. Robustness of social-ecological systems to spatial and temporal variability. Society \& Natural Resources 20(4):307-322. https://doi. org/10.1080/08941920601161320

Kaiser, B. A., M. Hoeberechts, K. H. Maxwell, L. EerkesMedrano, N. Hilmi, A. Safa, C. Horbel, S. K. Juniper, M. Roughan, N. T. Lowen, K. Short, and D. Paruru. 2019. The importance of connected ocean monitoring knowledge systems and communities. Frontiers in Marine Science 6:1-17. https://doi. org/10.3389/fmars.2019.00309

Kennett, R., M. Jackson, J. Morrison, and J. Kitchens. 2010. Indigenous rights and obligations to manage traditional land and sea estates in Northern Australia: the role of Indigenous rangers and the I-Tracker project. Policy Matters 17:135-142.

Kotaska, J. G. 2013. Reconciliation 'at the end of the day': decolonizing territorial governance in British Columbia after Delgamuukw. Dissertation. University of British Columbia, Vancouver, B.C., Canada. https://doi.org/10.14288/1.0074235

Kouril, D., C. Furgal, and T. Whillans. 2016. Trends and key elements in community-based monitoring: a systematic review of the literature with an emphasis on Arctic and Subarctic regions. Environmental Reviews 24:151-163. https://www.nrcresearchpress. com/doi/10.1139/er-2015-0041

Lam, S., W. Dodd, K. Skinner, A. Papadopoulos, C. Zivot, J. Ford, P. J. Garcia, and S. L. Harper. 2019. Community-based monitoring of Indigenous food security in a changing climate: global trends and future directions. Environmental Research Letters 14(7):073002. https://doi.org/10.1088/1748-9326/ab13e4

Langdon, S. J. 2006. Tidal pulse fishing: selective traditional Tlingit salmon fishing techniques on the west coast of the Prince of Wales Archipelago. Pages 21-46 in C. Menzies, editor. Traditional ecological knowledge and natural resource management. University of Nebraska Press, Lincoln, Nebraska, USA.

Lauer, M., and S. Aswani. 2010. Indigenous knowledge and longterm ecological change: detection, interpretation, and responses to changing ecological conditions in Pacific Island communities. Environmental Management 45:985-997. https://doi.org/10.1007/ $\underline{\text { s00267-010-9471-9 }}$
Lertzman, K. 2009. The paradigm of management, management systems, and resource stewardship. Journal of Ethnobiology 29 (2):339-358. https://doi.org/10.2993/0278-0771-29.2.339

Lindenmayer, D. B., and G. E. Likens. 2010. The science and application of ecological monitoring. Biological Conservation 143 (6):1317-1328. https://doi.org/10.1016/j.biocon.2010.02.013

Lyver, P. O. B., and Lutsël K'e Dene First Nation. 2005. Monitoring barren-ground caribou body condition with Denésoliné traditional knowledge. Arctic 58(1):44-54. https://doi. org/10.14430/arctic388

Lyver, P. O. B., S. J. Richardson, A. M. Gormley, P. Timoti, C. J. Jones, and B. L. Tahi. 2018. Complementarity of indigenous and western scientific approaches for monitoring forest state. Ecological Applications 28(7):1909-1923. https://doi.org/10.1002/ eap. 1787

Lyver, P. O. B., T. M. Taputu, S. T. Kutia, and B. Tahi. 2008. Tûhoe Tuawhenua Mâtauranga of Kererû (Hemiphaga novaseelandiae novaseelandiae) in Te Urewera. New Zealand Journal of Ecology 32(1):7-17.

Lyver, P. O. B., P. Timoti, C. J. Jones, S. J. Richardson, B. L. Tahi, and S. Greenhalgh. 2017. An indigenous community-based monitoring system for assessing forest health in New Zealand. Biodiversity and Conservation 26(13):3183-3212. https://doi. org/10.1007/s10531-016-1142-6

McCullough, E. B., and P. A. Matson. 2011. Evolution of the knowledge system for agricultural development in the Yaqui Valley, Sonora, Mexico. Proceedings of the National Academy of Sciences of the United States of America 113(17):4609-4614. https://doi.org/10.1073/pnas. 1011602108

McKay, A. J., and C. J. Johnson. 2017. Confronting barriers and recognizing opportunities: developing effective communitybased environmental monitoring programs to meet the needs of Aboriginal communities. Environmental Impact Assessment Review 64:16-25. https://doi.org/10.1016/j.eiar.2017.01.002

Moller, H., F. Berkes, P. O. B. Lyver, and M. Kislalioglu. 2004. Combining science and traditional ecological knowledge: monitoring populations for co-management. Ecology and Society 9(3):2. https://doi.org/10.5751/ES-00675-090302

Morishige, K., P. Andrade, P. Pascua, K. Steward, E. Cadiz, L. Kapono, and U. Chong. 2018. Nâ Kilo'Âina: Visions of biocultural restoration through Indigenous relationships between people and place. Sustainability 10(10):1-20. https://doi. org/10.3390/su10103368

Nadasdy, P. 1999. The politics of TEK: power and the "integration" of knowledge. Arctic Anthropology 36(1-2): 1-18.

Negi, V. S., P. Kewlani, R. Pathak, D. Bhatt, I. D. Bhatt, R. S. Rawal, R. C. Sundriyal, and S. K. Nandi. 2018. Criteria and indicators for promoting cultivation and conservation of medicinal and aromatic plants in Western Himalaya, India. Ecological Indicators 93:434-446. https://doi.org/10.1016/j. ecolind.2018.03.032

Nichols, T., F. Berkes, D. Jolly, and N. B. Snow. 2004. Climate change and sea ice: local observations from the Canadian western arctic. Arctic 57(1):68-79. https://doi.org/10.14430/arctic484 
Oba, G., P. Byakagaba, and A. Angassa. 2008. Participatory monitoring of biodiversity in East African grazing lands. Land Degradation \& Development 19(6):636-648. https://doi.org/10.1002/ $\underline{\text { ldr.867 }}$

Olivero, J., F. Ferri, P. Acevedo, J. M. Lobo, J. E. Fa, M. A. Farfan, and D. Romero. 2016. Using indigenous knowledge to link hypertemporal land cover mapping with land use in the Venezuelan Amazon: "The Forest Pulse." Revista de Biología Tropical 64 (4):1661-1682. https://doi.org/10.15517/rbt.v64i4.21886

Ostertag, S. K., L. L. Loseto, K. Snow, J. Lam, K. Hynes, and D. V. Gillman. 2018. "That's how we know they're healthy": the inclusion of traditional ecological knowledge in beluga health monitoring in the Inuvialuit Settlement Region. Arctic Science 4 (3):292-320. https://doi.org/10.1139/as-2017-0050

Ostrom, E. 2009. A general framework for analyzing sustainability of social-ecological systems. Science 325 (5939):419-422. https://doi.org/10.1126/science.1172133

Pacheco-Cobos, L., M. F. Rosetti, A. M. Esquivel, and R. Hudson. 2015. Towards a traditional ecological knowledge-based monitoring scheme: a proposal for the case of edible mushrooms. Biodiversity and Conservation 24:1253-1269. https://doi. org/10.1007/s10531-014-0856-6

Paltsyn, M. Y., J. P. Gibbs, and G. Mountrakis. 2019. Integrating traditional ecological knowledge and remote sensing for monitoring rangeland dynamics in the Altai Mountain region. Environmental Management 64(1):40-51. https://doi.org/10.1007/ s00267-018-01135-6

Paneque-Gálvez, J., N. Vargas-Ramírez, B. M. Napoletano, and A. Cummings. 2017. Grassroots innovation using drones for Indigenous mapping and monitoring. Land 6(4):86. https://doi. org/10.3390/land6040086

Parlee, B., M. Manseau, and Lutsël K'e Dene First Nation. 2005. Using traditional knowledge to adapt to ecological change: Denésoliné monitoring of caribou movements. Arctic 58 (1):26-37. https://doi.org/10.14430/arctic386

Parry, L., and C. A. Peres. 2015. Evaluating the use of local ecological knowledge to monitor hunted tropical-forest wildlife over large spatial scales. Ecology and Society 20(3):15. https://doi. org/10.5751/ES-07601-200315

Prober, S. M., M. H. O. Connor, and F. J. Walsh. 2011. Australian Aboriginal peoples' seasonal knowledge: a potential basis for shared understanding in environmental management. Ecology and Society 16(2):12. https://doi.org/10.5751/ES-04023-160212

Pulsifer, P., S. Gearheard, H. P. Huntington, M. A. Parsons, C. McNeave, and H. S. McCann. 2012. The role of data management in engaging communities in Arctic research: overview of the Exchange for Local Observations and Knowledge of the Arctic (ELOKA). Polar Geography 35(3-4):271-290. https://doi. org/10.1080/1088937X.2012.708364

Riseth, J. A., H. Tømmervik, E. Helander-Renvall, N. Labba, C. Johansson, E. Malnes, J. W. Bjerke, C. Jonsson, V. Pohjola, L.-E. Sarri, A. Schanche, and T. V. Callaghan. 2011. Sámi traditional ecological knowledge as a guide to science: snow, ice and reindeer pasture facing climate change. Polar Record 47(3):202-217. https://doi.org/10.1017/S0032247410000434
Roba, H. G., and G. Oba. 2008. Integration of herder knowledge and ecological methods for land degradation assessment around sedentary settlements in a sub-humid zone in northern Kenya. International Journal of Sustainable Development and World Ecology 15:251-264. https://doi.org/10.3843/SusDev.15.3:8

Roba, H. G., and G. Oba. 2009. Community participatory landscape classification and biodiversity assessment and monitoring of grazing lands in northern Kenya. Journal of Environmental Management 90(2):673-682. https://doi.org/10.1016/ j.jenvman.2007.12.017

Schuster, R., R. R. Germain, J. R. Bennett, N. J. Reo, and P. Arcese. 2019. Vertebrate biodiversity on indigenous-managed lands in Australia, Brazil, and Canada equals that in protected areas. Environmental Science \& Policy 101:1-6. https://doi. org/10.1016/j.envsci.2019.07.002

Setty, R. S., K. Bawa, T. Ticktin, and C. M. Gowda. 2008. Evaluation of a participatory resource monitoring system for nontimber forest products: the case of amla (Phyllanthus spp.) fruit harvest by Soligas in south India. Ecology and Society 13 (2):19. https://doi.org/10.5751/ES-02510-130219

Shaffer, L. J. 2014. Making sense of local climate change in rural Tanzania through knowledge co-production. Journal of Ethnobiology 34(3):315-334. https://doi.org/10.2993/0278-0771-34.3.315

Sheil, D., M. Boissière, and G. Beaudoin. 2015. Unseen sentinels: local monitoring and control in conservation's blind spots. Ecology and Society 20(2):39. https://doi.org/10.5751/ES-07625-200239

Shrestha, Y., and R. Lapeyre. 2018. Modern wildlife monitoring technologies: conservationists versus communities? A case study: the Terai-Arc landscape, Nepal. Conservation \& Society 16 (1):91-101. https://doi.org/10.4103/cs.cs 1683

Simpson, L. B. 2000. Aboriginal peoples and knowledge: decolonizing our processes. Canadian Journal of Native Studies 1 (21):137-148. http://www3.brandonu.ca/cjns/21.1/cjnsv21no1 pg137-148. pdf

Simpson, L. B. 2014. Land as pedagogy: Nishnaabeg intelligence and rebellious transformation. Decolonization: Indigeneity, Education \& Society 3(3):1-25. https://jps.library.utoronto.ca/ index.php/des/article/view/22170

Sterling, E., T. Ticktin, T. Kipa, K. Morgan, G. Cullman, D. Alvira, P. Andrade, N. Bergamini, E. Betley, K. Burrows, S. Caillon, J. Claudet, R. Dacks, P. Eyzaguirre, C. Filardi, N. Gazit, C. Giardina, S. Jupiter, K. Kinney, J. McCarter, M. Mejia, K. Morishige, J. Newell, L. Noori, J. Parks, P. Pascua, A. Ravikumar, J. Tanguay, A. Sigouin, T. Stege, M. Stege, and A. Wali. 2017. Culturally grounded indicators of resilience in social-ecological systems. Environment and Society 8:63-95. https://doi. org/10.3167/ares.2017.080104

Stori, F. T., C. M. Peres, A. Turra, and R. L. Pressey. 2019. Traditional ecological knowledge supports ecosystem-based management in disturbed coastal marine social-ecological systems. Frontiers in Marine Science 6:1-22. https://doi. org/10.3389/fmars.2019.00571

Thompson, K.-L., N. Reece, N. Robinson, H.-J. Fisher, N. C. Ban, and C. Picard. 2019. "We monitor by living here": communitydriven actualization of a social-ecological monitoring program 
based in the knowledge of Indigenous harvesters. Facets 4:293-314. https://doi.org/10.1139/facets-2019-0006

Thornton, T. F., and A. M. Scheer. 2012. Collaborative engagement of local and traditional knowledge and science in marine environments: a review. Ecology and Society 17(3):8. https://doi.org/10.5751/ES-04714-170308

Torres, A. B., L. A. S. Acuña, and J. M. C. Vergara. 2014. Integrating $\mathrm{CBM}$ into land-use based mitigation actions implemented by local communities. Forests 5(12):3295-3326. https://doi.org/10.3390/f5123295

Trosper, R. L. 2002. Northwest Coast Indigenous institutions that supported resilience and sustainability. Ecological Economics 41 (2):329-344. https://doi.org/10.1016/S0921-8009(02)00041-1

Turner, N. J., and F. Berkes. 2006. Coming to understanding: developing conservation through incremental learning in the Pacific Northwest. Human Ecology 34(4):495-513. https://doi. org/10.1007/s10745-006-9042-0

Turner, N. J., and D. Deur. 2013. Plant management systems of British Columbia's First Peoples. BC Studies 179:107-133. https:// doi.org/10.14288/bcs.v0i179.184112

Turreira-García, N., J. F. Lund, P. Domínguez, E. CarrilloAnglés, M. C. Brummer, and P. Duenn. 2018. What's in a name? Unpacking "participatory" environmental monitoring. Ecology and Society 23(2):24. https:/doi.org/10.5751/ES-10144-230224

United Nations Conference on Environment \& Development. 1992. Agenda 21, Rio Declaration, Forest Principles. United Nations, editor. https://sustainabledevelopment.un.org/content/ documents/Agenda21.pdf

United Nations Permanent Forum on Indigenous Issues. n.d. Who are indigenous peoples? https://www.un.org/esa/socdev/ unpfii/documents/5session factsheet1.pdf

Wilson, N. J., E. Mutter, J. Inkster, and T. Satterfield. 2018. Community-based monitoring as the practice of Indigenous governance: a case study of Indigenous-led water quality monitoring in the Yukon River Basin. Journal of Environmental Management 210:290-298. https://doi.org/10.1016/j.jenvman.2018.01.020

Wilson, S. 2001. What is Indigenous research methodology? Canadian Journal of Native Education 25(2):166-174.

Wiseman, N. D., and D. K. Bardsley. 2016. Monitoring to learn, learning to monitor: a critical analysis of opportunities for Indigenous community-based monitoring of environmental change in Australian rangelands. Geographical Research 54 (1):52-71. https://doi.org/10.1111/1745-5871.12150

Wyndham, F. S. 2017. The trouble with TEK. Ethnobiology Letters 8(1):78-80. https://doi.org/10.14237/ebl.8.1.2017.1006 


\section{Appendix 1.}

Table A1.1. Reviewed literature, participating Indigenous groups, and categorization of participation

\begin{tabular}{|c|c|c|c|c|}
\hline References & $\begin{array}{l}\text { Case study/ Initiative } \\
\text { Name }\end{array}$ & $\begin{array}{l}\text { Indigenous peoples (as } \\
\text { named in the literature) }\end{array}$ & $\begin{array}{l}\text { Weighted } \\
\text { participation } \\
\text { score }\end{array}$ & $\begin{array}{l}\text { Category of } \\
\text { participation }\end{array}$ \\
\hline Alessa et al., 2016 & NA & $\begin{array}{l}\text { Aleut, Central Yup'ik, } \\
\text { Chuchki, Koryak, } \\
\text { Siberian Yup'ik, } \\
\text { Inuvialuit }\end{array}$ & 51 & 2 \\
\hline $\begin{array}{l}\text { Aswani \& Weiant, } \\
2004\end{array}$ & NA & Roviana & 58 & 3 \\
\hline \multirow[t]{2}{*}{ Bell \& Harwood, 2012} & $\begin{array}{l}\text { Inuvialuit Harvest } \\
\text { Study }\end{array}$ & Inuvialuit & 66 & 3 \\
\hline & Beluga Whale Study & Inuvialuit & 23 & 1 \\
\hline Bellfield et al., 2015 & REDD+ & Makushi & 52 & 3 \\
\hline Berkes et al., 2007 & $\begin{array}{l}\text { Inuit Bowhead } \\
\text { knowledge study }\end{array}$ & Inuit & 72 & 4 \\
\hline Brammer et al., 2016 & I-Tracker & $\begin{array}{l}\text { Inuit, Gwich'in, Cree, } \\
\text { Anicinapek, Indigenous } \\
\text { peoples of Australia, Ca } \\
\text { Dong }\end{array}$ & 57 & 3 \\
\hline Brook et al., 2009 & $\begin{array}{l}\text { Sahtu Wildlife Health } \\
\text { Outreach and } \\
\text { Monitoring Program }\end{array}$ & Sahtu Dene, Metis & 43 & 2 \\
\hline Chambers et al., 2017 & $\begin{array}{l}\text { Climate and Oceans } \\
\text { Support Program }\end{array}$ & $\begin{array}{l}\text { Indigenous people of } \\
\text { Australia, Micronesia, } \\
\text { Melanesia and Polynesia }\end{array}$ & 57 & 3 \\
\hline Constantino et al., 2008 & NA & Kaxinawá & 60 & 3 \\
\hline \multirow[t]{4}{*}{ Constantino et al., 2012} & $\begin{array}{l}\text { Hunting in Indigenous } \\
\text { Lands (HIL) }\end{array}$ & Kaxinawá & 47 & 3 \\
\hline & $\begin{array}{l}\text { Biodiversity and } \\
\text { Natural Resources } \\
\text { Monitoring Use } \\
\text { Program of Amazonas } \\
\text { Protected Areas } \\
\text { (ProBUC) }\end{array}$ & Ribeirinho & 54 & 3 \\
\hline & $\begin{array}{l}\text { Fauna Monitoring } \\
\text { System of the } \\
\text { Mamiraua Institute } \\
\text { (SMUF) }\end{array}$ & Ribeirinho & 54 & 3 \\
\hline & Event Book System & $\begin{array}{l}\text { Unnamed Indigenous } \\
\text { people of Namibia }\end{array}$ & 62 & 3 \\
\hline Cummings et al., 2017 & NA & Makushi, Wapishiana & 40 & 2 \\
\hline Danielsen et al., 2005 & NA & $\begin{array}{l}\text { Indigenous peoples of the } \\
\text { Philippines }\end{array}$ & 62 & 3 \\
\hline Danielsen et al., 2014 & NA & $\begin{array}{l}\text { Communities of Akunaaq, } \\
\text { Kitsissuarsuit, Ilulissat } \\
\text { and Qaarsut }\end{array}$ & 68 & 4 \\
\hline Dobbs et al., 2016 & NA & Nyul Nyul & 69 & 4 \\
\hline Dowsley, 2009 & NA & Inuit & 39 & 2 \\
\hline Dubé et al., 2013 & $\begin{array}{l}\text { Cumulative watershed } \\
\text { effects assessment of }\end{array}$ & $\begin{array}{l}\text { "70 First Nations and } \\
\text { Tribes" }\end{array}$ & 31 & 1 \\
\hline
\end{tabular}




\begin{tabular}{|c|c|c|c|c|}
\hline & the Yukon River & & & \\
\hline Eamer, 2006 & $\begin{array}{l}\text { Arctic Borderlands } \\
\text { Ecological Knowledge } \\
\text { Cooperative }\end{array}$ & $\begin{array}{l}\text { Inupiat, Inuvialuit, } \\
\text { Gwich'in }\end{array}$ & 64 & 3 \\
\hline Ens et al., 2010 & NA & Indigenous Australians & 56 & 3 \\
\hline $\begin{array}{l}\text { Fernandez-Gimenez et } \\
\text { al., } 2006\end{array}$ & $\begin{array}{l}\text { Alaska Beluga Whale } \\
\text { Committee }\end{array}$ & Alaska Native hunters & NA & $\mathrm{NA}$ \\
\hline $\begin{array}{l}\text { Garcia \& Lescuyer, } \\
2008\end{array}$ & Synthesis & $\begin{array}{l}\text { Unnamed Indigenous } \\
\text { groups in Cameroon and } \\
\text { India }\end{array}$ & NA & NA \\
\hline Gearheard et al., 2011 & Igliniit project & Inuit & 64 & 3 \\
\hline $\begin{array}{l}\text { Gérin-Lajoie et al., } \\
2018\end{array}$ & IMALIRIJIIT & Inuit & 45 & 2 \\
\hline Gill et al., 2014 & NA & Teett'it Gwich'in & 64 & 3 \\
\hline Grech et al., 2014 & NA & Yanyuwa & 65 & 3 \\
\hline $\begin{array}{l}\text { Harmsworth et al., } \\
2011\end{array}$ & NA & Māori & 29 & 1 \\
\hline Heaslip, 2008 & NA & Kwakwaka'wakw & 39 & 1 \\
\hline Jamsranjav et al., 2019 & NA & Mongolian Herders & 45 & 2 \\
\hline Kaiser et al., 2019 & Review & Rakiura Māori, Inuit & NA & NA \\
\hline Kennett et al., 2010 & $\begin{array}{l}\text { NAILSMA Cyber- } \\
\text { tracker }\end{array}$ & $\begin{array}{l}\text { Aboriginal and Torres } \\
\text { Strait Islander People }\end{array}$ & 74 & 4 \\
\hline \multirow[t]{3}{*}{ Kipp et al., 2019} & CBWMN, CEMP & Arctic communities & 47 & 2 \\
\hline & SmartICE & Arctic communities & 55 & 3 \\
\hline & ENuk, ISR-CBMP & Arctic communities & 63 & 3 \\
\hline Kouril et al., 2016 & Review & $\begin{array}{l}\text { Vezo, Hehe \& Diani, } \\
\text { Soliga, Sama-Bajou } \\
\text { Adivasi, Aboriginal } \\
\text { peoples, Indigenous } \\
\text { Fijians, First Nations, } \\
\text { Metis, Inuit, Cofan } \\
\text { Indians of Aguarico, } \\
\text { Kichwa }\end{array}$ & NA & NA \\
\hline Lam et al., 2019 & Review & $\begin{array}{l}\text { First Nations, Inuit, } \\
\text { Kaxinawá, Isoseno- } \\
\text { Guarani, Waiwai, } \\
\text { Xerente, Makushi, } \\
\text { Matsigenka, Kitchwa, } \\
\text { Purepecha, Andean } \\
\text { Amerindian, Indigenous } \\
\text { groups of Oceania, } \\
\text { Indigenous groups of } \\
\text { Africa, Indigenous groups } \\
\text { of Adia, Native } \\
\text { Americans }\end{array}$ & NA & NA \\
\hline Lauer \& Aswani, 2010 & NA & Munda and Nusa Roviana & 48 & 2 \\
\hline Leonard et al., 2013 & NA & Miriwoong & 47 & 2 \\
\hline Liebenberg et al., 1998 & Cybertracker & San & 41 & 2 \\
\hline $\begin{array}{l}\text { Lyver \& Lutsel K’e } \\
\text { Dene First Nation, } \\
2005\end{array}$ & NA & Łutsël K’é Denésoliné & 23 & 1 \\
\hline Lyver et al., 2008 & NA & Tūhoe Tuawhenua Māori & 54 & 3 \\
\hline Lyver et al., 2017 & NA & Māori & 51 & 2 \\
\hline Phil O.B. Lyver et al., & NA & Tūhoe Tuawhenua Māori & 51 & 2 \\
\hline
\end{tabular}




\begin{tabular}{|c|c|c|c|c|}
\hline 2018 & & & & \\
\hline $\begin{array}{l}\text { McKay \& Johnson, } \\
2017\end{array}$ & NA & Takla Lake First Nation & 31 & 1 \\
\hline Moller et al., 2004 & NA & $\begin{array}{l}\text { James Bay Cree, Rakiura } \\
\text { Māori, Dene, Inuit }\end{array}$ & 78 & 4 \\
\hline Morishige et al., 2018 & Nã Kilo’Ãina Program & Native Hawaiians & 60 & 3 \\
\hline $\begin{array}{l}\text { Mustonen \& } \\
\text { Tossavainen, } 2018\end{array}$ & NA & Unnamed & 23 & 1 \\
\hline Negi et al., 2018 & NA & "Tribal people" & 26 & 1 \\
\hline Nichols et al., 2004 & $\begin{array}{l}\text { Inuit Observations of } \\
\text { Climate Change } \\
\text { (IOCC) project }\end{array}$ & Inuit & 54 & 3 \\
\hline Noss, 2013 & NA & Isoseño-Guaraní & 63 & 3 \\
\hline Oba et al., 2008 & NA & Banyarwanda & 45 & 2 \\
\hline Olivero et al., 2016 & Forest Pulse & $\begin{array}{l}\text { Baniva, Bare, Kuripaco, } \\
\text { Warekena, Yeral }\end{array}$ & 48 & 2 \\
\hline Ostertag et al., 2018 & $\begin{array}{l}\text { Fish and Marine } \\
\text { Mammal Community } \\
\text { Monitoring Program }\end{array}$ & Inuvialuit & 63 & 3 \\
\hline $\begin{array}{l}\text { Oviedo \& Bursztyn, } \\
2017\end{array}$ & NA & Kaxinawá & 48 & 2 \\
\hline $\begin{array}{l}\text { Pacheco-Cobos et al., } \\
2015\end{array}$ & NA & Unnamed & 31 & 1 \\
\hline Paltsyn et al., 2019 & NA & $\begin{array}{l}\text { Indigenous Kazakhs, } \\
\text { Altaians }\end{array}$ & 25 & 1 \\
\hline $\begin{array}{l}\text { Paneque-Gálvez et al., } \\
2017\end{array}$ & NA & $\begin{array}{l}\text { Kukama Kukamiria, } \\
\text { Waphichana, Makushi, } \\
\text { Harakmbut, Embera- } \\
\text { Woonaan }\end{array}$ & 46 & 2 \\
\hline Parlee et al., 2005 & NA & Denésoliné & 64 & 3 \\
\hline Parlee et al., 2012 & NA & Lesser Slave Lake Cree & 31 & 1 \\
\hline Parry \& Peres, 2015 & NA & $\begin{array}{l}\text { "Amazonian river } \\
\text { dwellers" }\end{array}$ & 24 & 1 \\
\hline Prober et al., 2011 & NA & $\begin{array}{l}\text { Walpiri, Torres Strait } \\
\text { Islander Peoples }\end{array}$ & 60 & 3 \\
\hline Pulsifer et al., 2012 & Review & Inuit & NA & NA \\
\hline $\begin{array}{l}\text { Reyes-García et al., } \\
2019\end{array}$ & Review & $\begin{array}{l}\text { Indigenous peoples } \\
\text { worldwide }\end{array}$ & NA & NA \\
\hline Riseth et al., 2011 & NA & Sámi & 27 & 1 \\
\hline Roba \& Oba, 2008 & NA & Aarial & 25 & 1 \\
\hline Roba \& Oba, 2009b & NA & Aarial & 33 & 1 \\
\hline Roba \& Oba, 2009a & NA & Rendille & 353 & 3 \\
\hline Russell et al., 2013 & $\begin{array}{l}\text { Arctic Borderlands } \\
\text { Ecological Knowledge } \\
\text { Cooperative }\end{array}$ & $\begin{array}{l}\text { Communities of Aklavik, } \\
\text { Fort MacPHerson, } \\
\text { Tsiigehtchic, } \\
\text { Tukutoyuktuk, Old Crow, } \\
\text { Arctic Village, Kaktovik }\end{array}$ & 53 & 3 \\
\hline Setty et al., 2008 & NA & Soliga & 56 & 3 \\
\hline Shaffer, 2014 & NA & $\begin{array}{l}\text { Communities of } \\
\text { Mlingotini, Makurunge, } \\
\text { Chekereni, Rau }\end{array}$ & 58 & 3 \\
\hline Sheil et al., 2015 & NA & $\begin{array}{l}\text { Kwersa, Torweja, } \\
\text { Wekerig, Kawera, Paito, } \\
\text { Bosumbaso }\end{array}$ & 81 & 4 \\
\hline Shrestha \& Lapeyre, & NA & Adivasi Janajati & 36 & 1 \\
\hline
\end{tabular}




\begin{tabular}{|c|c|c|c|c|}
\hline 2018 & & & & \\
\hline Steiner et al., 2019 & CEE Model & Inuvialuit & NA & NA \\
\hline Stori et al., 2019 & NA & Caicara & 60 & 3 \\
\hline Straka et al., 2018 & NA & Dene, Cree, Metis & 35 & 1 \\
\hline Thompson et al., 2019 & $\begin{array}{l}\text { "We monitor by living } \\
\text { here" project }\end{array}$ & Gitga'at & 69 & 4 \\
\hline Torres et al., 2014 & REDD+ monitoring & $\begin{array}{l}\text { Indigenous communities } \\
\text { of Guadalupe y Calvo and } \\
\text { Hopelchén }\end{array}$ & 53 & 2 \\
\hline Tremblay et al., 2008 & NA & Inuit, Naskapi & 72 & 4 \\
\hline Wheeler et al., 2019 & Review & Pan-arctic communities & NA & NA \\
\hline Wilson et al., 2018 & $\begin{array}{l}\text { Indigenous } \\
\text { Observation Network } \\
\text { (ION) }\end{array}$ & $\begin{array}{l}\text { Carcross/Tagish, Kluane, } \\
\text { Selkirk, Tr'ondëk } \\
\text { Hwëch'in, White River } \\
\text { First Nation, Taku River } \\
\text { Tlingit First Nation }\end{array}$ & 39 & 2 \\
\hline $\begin{array}{l}\text { Wiseman \& Bardsley, } \\
2016\end{array}$ & NA & $\begin{array}{l}\text { Pitjantjatjara, } \\
\text { Yankunytjatjara, } \\
\text { Ngaanyatjaara }\end{array}$ & 57 & 3 \\
\hline Ziembicki et al., 2013 & NA & $\begin{array}{l}\text { Aboriginal peoples of the } \\
\text { Arnhem Plateau, Australia }\end{array}$ & 32 & 1 \\
\hline
\end{tabular}

\section{Bibliography of papers reviewed}

Alessa, L., Kliskey, A., Gamble, J., Fidel, M., Beaujean, G., \& Gosz, J. (2016). The Role of Indigenous Science and Local Knowledge in Integrated Observing Systems: Moving Toward Adaptive Capacity Indices and Early Warning Systems. Sustainability Science, 11, 91-102. https://doi.org/10.1007/s11625-015-0295-7

Aswani, S., \& Weiant, P. (2004). Scientific Evaluation in Women's Participatory Management: Monitoring Marine Invertebrate Refugia in the Solomon Islands. Human Organization, 63(3), 301-319.

Bell, R. K., \& Harwood, L. A. (2012). Harvest-based Monitoring in the Inuvialuit Settlement Region : Steps for Success. Arctic, 65(4), 421-432.

Bellfield, H., Sabogal, D., Goodman, L., \& Leggett, M. (2015). Case Study Report: CommunityBased Monitoring Systems for REDD+ in Guyana. Forests, 6, 133-156. https://doi.org/10.3390/f6010133

Berkes, F., Berkes, M. K., \& Fast, H. (2007). Collaborative Integrated Management in Canada's North: The Role of Local and Traditional Knowledge and Community-Based Monitoring. Coastal Management, 35, 143-162. https://doi.org/10.1080/08920750600970487

Brammer, J. R., Brunet, N. D., Burton, A. C., Cuerrier, A., Danielsen, F., Dewan, K., Herrmann, T. M., Jackson, M. V., Kennett, R., Larocque, G., Mulrennan, M., Pratihast, A. K., SaintArnaud, M., Scott, C., \& Humphries, M. M. (2016). The Role of Digital Data Entry in Participatory Environmental Monitoring. Conservation Biology, 30(6), 1277-1287. https://doi.org/10.1111/cobi.12727

Brook, R. K., Kutz, S. J., Veitch, A. M., Popko, R. A., Elkin, B. T., \& Guthrie, G. (2009). Fostering Community-Based Wildlife Health Monitoring and Research in the Canadian North. EcoHealth, 6, 266-278. https://doi.org/10.1007/s10393-009-0256-7

Chambers, L. E., Plotz, R. D., Dossis, T., Hiriasia, D. H., Malsale, P., Martin, D. J., Mitiepo, R., Tahera, K., \& Tofaeono, T. I. (2017). A database for traditional knowledge of weather and 
climate in the Pacific. Meteorological Applications. https://doi.org/10.1002/met.1648

Constantino, P. de A. L., Carlos, H. S. A., Ramalho, E. E., Rostant, L., Marinelli, C. E., Teles, D., Fonseca-Junior, S. F., Fernandes, R. B., \& Valsecchi, J. (2012). Empowering Local People through Community-based Resource Monitoring: a Comparison of Brazil and Namibia. Ecology and Society, 17(4), 22. http://dx.doi.org/10.5751ES-05164-170422

Constantino, P., Fortini, L., \& Kaxinawa, F. (2008). Indigenous Collaborative Research for Wildlife Management in Amazonia: The Case of the Kaxinawa. Biological Conservation, 141, 2718-2729. https://doi.org/10.1016/j.biocon.2008.08.008

Cummings, A. R., Cummings, G. R., Hamer, E., Moses, P., Norman, Z., Captain, V., Bento, R., \& Butler, K. (2017). Developing a UAV-Based Monitoring Program with Indigenous Peoples. Journal of Unmanned Vehicle Systems, 125(April), 115-125. https://doi.org/10.1139/juvs-2016-0022

Danielsen, F., Jensen, A. E., Alviola, P. A., Balete, D. S., Mendoza, M., Tagtag, A., Custodio, C., \& Enghoff, M. (2005). Does Monitoring Matter? A Quantitative Assessment of Management Decisions from Locally-based Monitoring of Protected Areas. Biodiversity and Conservation, 14, 2633-2652. https://doi.org/10.1007/s10531-005-8392-z

Danielsen, F., Jensen, P. M., Burgess, N. D., Altamirano, R., Alviola, P. A., Andraianandrasana, H., Brashares, J. S., Burton, A. C., Coronado, I., Corpuz, N., Enghoff, M., Funder, M., Holt, S., Jensen, A. E., Massao, J., Mendoza, M. M., Ngaga, Y., Pipper, C. B., Poulsen, M. K., ... Young, R. (2014). A Multicountry Assessment of Tropical Resource Monitoring by Local Communities. BioScience, 64(3), 236-251. https://doi.org/10.1093/biosci/biu001

Dobbs, R. J., Davies, C. L., Walker, M. L., Pettit, N. E., Pusey, B. J., Close, P. G., Akune, Y., Walsham, N., Smith, B., Wiggan, A., Cox, P., Ward, D. P., Tingle, F., Kennett, R., Jackson, M. V, \& Davies, P. M. (2016). Collaborative Research Partnerships Inform Monitoring and Management of Aquatic Ecosystems by Indigenous Rangers. Reviews in Fish Biology and Fisheries, 26, 711-725. https://doi.org/10.1007/s11160-015-9401-2

Dowsley, M. (2009). Community Clusters in Wildlife and Environmental Management: Using TEK and Community Involvement to Improve Co-Management in an Era of Rapid Environmental Change. Polar Research, 28(1), 43-59. https://doi.org/10.1111/j.17518369.2008.00093.x

Dubé, M. G., Wilson, J. E., \& Waterhouse, J. (2013). Accumulated State Assessment of the Yukon River watershed: Part II Quantitative Effects-Based Analysis Integrating Western Science and Traditional Ecological Knowledge. Integrated Environmental Assessment and Management, 9(3), 439-455. https://doi.org/10.1002/ieam.1363

Eamer, J. (2006). Keep It Simple and Be Relevant :The First Ten Years of the Arctic Borderlands Ecological Knowledge Co-op. Bridging Scales and Knowledge Systems, May 2011, 185-206.

Ens, E. J., Cooke, P., Nadjamerrek, R., Namundja, S., Garlngarr, V., \& Yibarbuk, D. (2010). Combining Aboriginal and non-Aboriginal Knowledge to Assess and Manage Feral Water Buffalo Impacts on Perennial Freshwater Springs of the Aboriginal-Owned Arnhem Plateau, Australia. Environmental Management, 45, 751-758. https://doi.org/10.1007/s00267-010-9452-Z

Fernandez-Gimenez, M. E., Huntington, H. P., \& Frost, K. J. (2006). Integration or co-optation? Traditional knowledge and science in the Alaska Beluga Whale Committee. Environmental Conservation, 33(04), 306. https://doi.org/10.1017/S0376892906003420

Garcia, C. A., \& Lescuyer, G. (2008). Monitoring, Indicators and Community Based Forest 
Management in the Tropics: Pretexts or Red Herrings? Biodiversity and Conservation, 17, 1303-1317. https://doi.org/10.1007/s10531-008-9347-y

Gearheard, S., Aporta, C., Aipellee, G., \& O’Keefe, K. (2011). The Igliniit project: Inuit Hunters Document Life on the Trail to Map and Monitor Arctic Change. The Canadian Geographer, 55(1), 42-55. https://doi.org/10.1111/j.1541-0064.2010.00344.x

Gérin-Lajoie, J., Herrmann, T. M., MacMillan, G. A., Hébert-Houle, É., Monfette, M., Rowell, J. A., Soucie, T. A., Snowball, H., Townley, E., Lévesque, E., Amyot, M., Franssen, J., \& Dedieu, J. P. (2018). IMALIRIJIIT: A Community-Based Environmental Monitoring Program in the George River Watershed, Nunavik,Canada. Ecoscience, 25(4), 381-399. https://doi.org/10.1080/11956860.2018.1498226

Gill, H., Lantz, T., \& Institute, G. S. and C. (2014). A Community-Based Approach to Mapping Gwich'in Observations of Environmental Changes in the Lower Peel River Watershed, NT. Journal of Ethnobiology, 34(3), 294-314.

Grech, A., Parra, G. J., Beasly, I., Bradley, J., Johnson, S., Whiting, S., li-Anthawirriyarra Sea Rangers, Yanyuwa Families, \& Marsh, H. (2014). Local Assessments of Marine Mammals in Cross-Cultural Environments. Biodiversity and Conservation, 23, 3319-3338. https://doi.org/10.1007/s10531-014-0783-6

Harmsworth, G. R., Young, R. G., Walker, D., Clapcott, J. E., \& James, T. (2011). Linkages Between Cultural and Scientific Indicators of River and Stream Health. New Zealand Journal of Marine and Freshwater Research, 45(3), 423-436. https://doi.org/10.1080/00288330.2011.570767

Heaslip, R. (2008). Monitoring Salmon Aquaculture Waste : The contribution of First Nations' Rights, Knowledge, and Practices in British Columbia, Canada. Marine Policy, 32, 988996. https://doi.org/10.1016/j.marpol.2008.02.002

Jamsranjav, C., Fernández-Giménez, M. E., Reid, R. S., \& Adya, B. (2019). Opportunities to integrate herders' indicators into formal rangeland monitoring: an example from Mongolia. Ecological Applications, 29(5), 1-20. https://doi.org/10.1002/eap.1899

Kaiser, B. A., Hoeberechts, M., Maxwell, K. H., Eerkes-medrano, L., Hilmi, N., Safa, A., Horbel, C., Juniper, S. K., Roughan, M., Lowen, N. T., Short, K., Paruru, D., Griffith, D. C., \& Kaiser, B. A. (2019). The Importance of Connected Ocean Monitoring Knowledge Systems and Communities. 6(June), 1-17. https://doi.org/10.3389/fmars.2019.00309

Kennett, R., Jackson, M., Morrison, J., \& Kitchens, J. (2010). Indigenous Rights and Obligations to Manage Traditional Land and Sea Estates in Northern Australia: The Role of Indigenous Rangers and the I-Tracker Project. Policy Matters, 17, 135-142.

Kipp, A., Cunsolo, A., Gillis, D., Sawatzky, A., \& Harper, S. L. (2019). The need for community-led, integrated and innovative monitoring programmes when responding to the health impacts of climate change. International Journal of Circumpolar Health, 78(2). https://doi.org/10.1080/22423982.2018.1517581

Kouril, D., Furgal, C., \& Whillans, T. (2016). Trends and Key Elements in Community-Based Monitoring: a Systematic Review of the Literature with an Emphasis on Arctic and Subarctic Regions. Environmental Reviews, 24(2016), 151-163. https://doi.org/dx.doi.org/10/1139/er-2015-0041

Lam, S., Dodd, W., Skinner, K., Papadopoulos, A., Zivot, C., Ford, J., Garcia, P. J., \& Harper, S. L. (2019). Community-based monitoring of Indigenous food security in a changing climate: global trends and future directions. Environmental Research Letters, 14(7), 073002. https://doi.org/10.1088/1748-9326/ab13e4 
Lauer, M., \& Aswani, S. (2010). Indigenous Knowledge and Long-term Ecological Change: Detection, Interpretation, and Responses to Changing Ecological Conditions in Pacific Island Communities. Environmental Management, 45, 985-997. https://doi.org/10.1007/s00267-010-9471-9

Leonard, S., Parsons, M., Olawsky, K., \& Kofod, F. (2013). The Role of Culture and Traditional Knowledge in Climate Change Adaptation: Insights from East Kimberley, Australia. Global Environmental Change, 23(23), 623-632.

Liebenberg, L., Blake, E., Steventon, L., Benadie, K., \& Minye, J. (1998). Integrating Traditional Knowledge with Computer Science for the Conservation of Biodiversity. 8th International Conference on Hunting and Gathering Societies.

Lyver, P. O., \& Lutsel K'e Dene First Nation. (2005). Monitoring barren-ground caribou body condition with Denesoline traditional knowledge. Arctic, 58(1), 44-54.

Lyver, P.O.B., Timoti, P., Jones, C. J., Richardson, S. J., Tahi, B. L., \& Greenhalgh, S. (2017). An indigenous community-based monitoring system for assessing forest health in New Zealand. Biodiversity and Conservation, 26, 3183-3212. https://doi.org/10.1007/s10531016-1142-6

Lyver, Phil O.B., Richardson, S. J., Gormley, A. M., Timoti, P., Jones, C. J., \& Tahi, B. L. (2018). Complementarity of indigenous and western scientific approaches for monitoring forest state. Ecological Applications, 28(7), 1909-1923. https://doi.org/10.1002/eap.1787

Lyver, Philip O Brian, Taputu, T. M., Kutia, S. T., \& Tahi, B. (2008). Tūhoe Tuawhenua Mātauranga of Kererū (Hemiphaga novaseelandiae novaseelandiae ) in Te Urewera. New Zealand Journal of Ecology, 32(1), 7-17.

McKay, A. J., \& Johnson, C. J. (2017). Confronting barriers and recognizing opportunities: Developing effective community-based environmental monitoring programs to meet the needs of Aboriginal communities. Environmental Impact Assessment Review, 64, 16-25. https://doi.org/10.1016/j.eiar.2017.01.002

Moller, H., Berkes, F., Lyver, P. O. B., \& Kislalioglu, M. (2004). Combining Science and Traditional Ecological Knowledge : Monitoring Populations for Co-Management. Ecology And Society, 9(3), 2. https://doi.org/papers3://publication/uuid/2AD26F8F-0011-489A805B-129CFCB55E06

Morishige, K., Andrade, P., Pascua, P., Steward, K., Cadiz, E., Kapono, L., \& Chong, U. (2018). Na; Kilo'A;ina: Visions of biocultural restoration through indigenous relationships between people and place. Sustainability (Switzerland), 10(10), 1-20. https://doi.org/10.3390/su10103368

Mustonen, T., \& Tossavainen, T. (2018). Brook lampreys of life: towards holistic monitoring of boreal aquatic habitats using 'subtle signs' and oral histories. Reviews in Fish Biology and Fisheries, 28(3), 657-665. https://doi.org/10.1007/s11160-018-9527-0

Negi, V. S., Kewlani, P., Pathak, R., Bhatt, D., Bhatt, I. D., Rawal, R. S., Sundriyal, R. C., \& Nandi, S. K. (2018). Criteria and indicators for promoting cultivation and conservation of Medicinal and Aromatic Plants in Western Himalaya, India. Ecological Indicators, 93(May), 434-446. https://doi.org/10.1016/j.ecolind.2018.03.032

Nichols, T., Berkes, F., Jolly, D., \& Snow, N. B. (2004). Arctic Western from the Canadian Climate Change and Sea Ice : Local Observations. Arctic, 57(1), 68-79.

Noss, R. F. (2013). Indicators for Monitoring Biodiversity: A Hierarchical Approach. Conservation Biology, 4(4), 355-364.

Oba, G., Byakagaba, P., \& Angassa, A. (2008). PARTICIPATORY MONITORING OF 
BIODIVERSITY IN EAST AFRICAN GRAZING LANDS. 648(October), 636-648. https://doi.org/10.1002/ldr

Olivero, J., Ferri, F., Acevedo, P., Lobo, J. M., Fa, J. E., Farfan, M. A., \& Romero, D. (2016). Using Indigenous Knowledge to Link Land Cover Mapping with Land use in the Venezuelan Amazon: "The Forest Pulse." Revista de Biología Tropical, 64(4), 1661-1682. https://doi.org/10.15517/rbt.v64i4.21886

Ostertag, S. K., Loseto, L. L., Snow, K., Lam, J., Hynes, K., \& Gillman, D. V. (2018). “That's how we know they're healthy": the inclusion of traditional ecological knowledge in beluga health monitoring in the Inuvialuit Settlement Region. Arctic Science, 320(May), 1-29. https://doi.org/10.1139/as-2017-0050

Oviedo, A. F. P., \& Bursztyn, M. (2017). Community-based monitoring of small-scale fisheries with digital devices in Brazilian Amazon. Fisheries Management and Ecology, 24(4), 320329. https://doi.org/10.1111/fme.12231

Pacheco-Cobos, L., Rosetti, M. F., Esquivel, A. M., \& Hudson, R. (2015). Towards a Traditional Ecological Knowledge-Based Monitoring Scheme: A Proposal for the Case of Edible Mushrooms. Biodiversity and Conservation, 24, 1253-1269. https://doi.org/10.1007/s10531-014-0856-6

Paltsyn, M. Y., Gibbs, J. P., \& Mountrakis, G. (2019). Integrating Traditional Ecological Knowledge and Remote Sensing for Monitoring Rangeland Dynamics in the Altai Mountain Region. Environmental Management, 64(1), 40-51. https://doi.org/10.1007/s00267-018-01135-6

Paneque-Gálvez, J., Vargas-Ramírez, N., Napoletano, B. M., \& Cummings, A. (2017). Grassroots innovation using drones for indigenous mapping and monitoring. Land, 6(4). https://doi.org/10.3390/land6040086

Parlee, B. L., Geertsema, K., \& Willier, A. (2012). Social-ecological thresholds in a changing boreal landscape: Insights from cree knowledge of the Lesser Slave Lake region of Alberta, Canada. Ecology and Society, 17(2). https://doi.org/10.5751/ES-04410-170220

Parlee, B., Manseau, M., Dene, Å. K. É., \& Nation, F. (2005). Using Traditional Knowledge to Adapt to Ecological Change: Denésôliné Monitoring of Caribou Movements. Arctic, 58(1), $26-37$.

Parry, L., \& Peres, C. A. (2015). Evaluating the Use of Local Ecological Knowledge to Monitor Hunted Tropical-Forest Wildlife over Large Spatial Scales. Ecology and Society, 20(3), 15. https://doi.org/10.5751/ES-07601-200315

Prober, S. M., Connor, M. H. O., \& Walsh, F. J. (2011). Australian Aboriginal Peoples' Seasonal Knowledge: a Potential Basis for Shared Understanding in Environmental Management. Ecology and Society, 16(2). http://www.ecologyandsociety.org/vol16/iss2/art12

Pulsifer, P., Gearheard, S., Huntington, H. P., Parsons, M. a., McNeave, C., \& McCann, H. S. (2012). The Role of Data Management in Engaging Communities in Arctic Research: Overview of the Exchange for Local Observations and Knowledge of the Arctic (ELOKA). Polar Geography, 35(3,4), 1-20. https://doi.org/10.1080/1088937X.2012.708364

Reyes-García, V., Fernández-Llamazares, Á., McElwee, P., Molnár, Z., Öllerer, K., Wilson, S. J., \& Brondizio, E. S. (2019). The contributions of Indigenous Peoples and local communities to ecological restoration. Restoration Ecology, 27(1), 3-8. https://doi.org/10.1111/rec.12894

Riseth, J. Å., Tømmervik, H., Helander-Renvall, E., Labba, N., Johansson, C., Malnes, E., Bjerke, J. W., Jonsson, C., Pohjola, V., Sarri, L.-E., Schanche, A., \& Callaghan, T. V. 
(2011). Sámi Traditional Ecological Knowledge as a Guide to Science: Snow, Ice and Reindeer Pasture Facing Climate Change. Polar Record, 47(03), 202-217.

https://doi.org/10.1017/S0032247410000434

Roba, H. G., \& Oba, G. (2008). Integration of Herder Knowledge and Ecological Methods for Land Degradation Assessment Around Sedentary Settlements in a Sub-Humid Zone in Northern Kenya. International Journal of Sustainable Development and World Ecology, 15, 251-264. https://doi.org/10.3843/SusDev.15.3

Roba, H. G., \& Oba, G. (2009a). Community Participatory Landscape Classification and Biodiversity Assessment and Monitoring of Grazing Lands in Northern Kenya. Journal of Environmental Management, 90, 673-682. https://doi.org/10.1016/j.jenvman.2007.12.017

Roba, H. G., \& Oba, G. (2009b). Efficacy of Integrating Herder Knowledge and Ecological Methods for Monitoring Rangeland Degradation in Northern Kenya. Human Ecology, 37(5), 589-612.

Russell, D. E., Svoboda, M. Y., Arokium, J., \& Cooley, D. (2013). Arctic Borderlands Ecological Knowledge Cooperative: Can Local Knowledge Inform Caribou Management? Rangifer, 33(21), 71-78.

http://search.ebscohost.com/login.aspx?direct=true $\& \mathrm{db}=\mathrm{a} 9 \mathrm{~h} \& \mathrm{AN}=90557185 \&$ site $=$ ehostlive

Setty, R. S., Bawa, K., Ticktin, T., \& Gowda, C. M. (2008). Evaluation of a Participatory Resource Monitoring System for Nontimber Forest Products: the Case of Amla (Phyllanthus spp .) Fruit Harvest by Soligas in South India. Ecology and Society, 13(2). http://www.ecologyandsociety.org/vol13/iss2/art19

Shaffer, L. J. (2014). Making Sense of Local Climate Change in Rural Tanzania Through Knowledge Co-Production. Journal of Ethnobiology, 34(3), 315-334. https://doi.org/10.2993/0278-0771-34.3.315

Sheil, D., Boissière, M., \& Beaudoin, G. (2015). Unseen Sentinels: Local Monitoring and Control in Conservation's Blind Spots. Ecology and Society, 20(2is). https://doi.org/10.5751/ES-07625-200239

Shrestha, Y., \& Lapeyre, R. (2018). Modern Wildlife Monitoring Technologies: Conservationists versus Communities? A Case Study: The Terai-Arc Landscape, Nepal. Conservation and Society, 16(1), 91-101. https://doi.org/10.4103/cs.cs

Steiner, N. S., Cheung, W. W. L., Cisneros-Montemayor, A. M., Drost, H., Hayashida, H., Hoover, C., Lam, J., Sou, T., Sumaila, U. R., Suprenand, P., Tai, T. C., \& VanderZwaag, D. L. (2019). Impacts of the changing ocean-sea ice system on the key forage fish arctic cod (Boreogadus saida) and subsistence fisheries in the Western Canadian arctic-evaluating linked climate, ecosystem and economic (CEE) models. Frontiers in Marine Science, 6(APR). https://doi.org/10.3389/fmars.2019.00179

Stori, F. T., Peres, C. M., Turra, A., \& Pressey, R. L. (2019). Traditional ecological knowledge supports ecosystem-based management in disturbed coastal marine social-ecological systems. Frontiers in Marine Science, 6(SEP), 1-22. https://doi.org/10.3389/fmars.2019.00571

Straka, J. R., Antoine, A., Bruno, R., Campbell, D., Campbell, R., Campbell, R., Cardina, J., Gibot, G., Gray, Q. Z., Irwin, S., Kindopp, R., Ladouceur, R., Ladouceur, W., Lankshear, J., Maclean, B., Macmillan, S., Marcel, F., Marten, G., Marten, L., ... Wiltzen, L. (2018). We used to say rats fell from the sky after a flood: Temporary recovery of muskrat following ice jams in the peace-athabasca delta. Arctic, 71(2), 218-228. 
https://doi.org/10.14430/arctic4714

Thompson, K.-L., Reece, N., Robinson, N., Fisher, H.-J., Ban, N. C., \& Picard., C. (2019). "We monitor by living here": Community-driven actualization of a social-ecological monitoring program based in the knowledge of Indigenous harvesters. Facets, 4, 293-314. https://doi.org/10.1139/facets-2019-0006

Torres, A. B., Acuña, L. A. S., \& Vergara, J. M. C. (2014). Integrating CBM into Land-Use Based Mitigation Actions Implemented by Local Communities. Forests, 5(12), 3295-3326. https://doi.org/10.3390/f5123295

Tremblay, M., Furgal, C., Larrivée, C., Annanack, T., Tookalook, P., Qiisik, M., Angiyou, E., Swappie, N., Savard, J., Tremblay, M., Furgal, C., Larrivée, C., Annanack, T., Tookalook, P., Qiisik, M., Angiyou, E. L. I., Swappie, N., Savard, J., \& Barrett, M. (2008). Climate Change in Northern Quebec: Adaptation Strategies from Community-Based Research. Arctic, 61(1), 27-34.

Wheeler, H. C., Berteaux, D., Furgal, C., Cazelles, K., Yoccoz, N. G., \& Grémillet, D. (2019). Identifying key needs for the integration of social-ecological outcomes in arctic wildlife monitoring. Conservation Biology, 33(4), 861-872. https://doi.org/10.1111/cobi.13257

Wilson, N. J., Mutter, E., Inkster, J., \& Satterfield, T. (2018). Community-Based Monitoring as the practice of Indigenous governance: A case study of Indigenous-led water quality monitoring in the Yukon River Basin. Journal of Environmental Management, 210, 290 298. https://doi.org/10.1016/j.jenvman.2018.01.020

Wiseman, N. D., \& Bardsley, D. K. (2016). Monitoring to Learn, Learning to Monitor: A Critical Analysis of Opportunities for Indigenous Community-Based Monitoring of Environmental Change in Australian Rangelands. Geographical Research, 54(1), 52-71. https://doi.org/10.1111/1745-5871.12150

Ziembicki, M. R., Woinarski, J. C. Z., \& Mackey, B. (2013). Evaluating the Status of Species using Indigenous knowledge: Novel Evidence for major Native Mammal Declines in Northern Australia. Biological Conservation, 157, 78-92. https://doi.org/10.1016/j.biocon.2012.07.004 
Appendix 2. Appendix 2. Data

Please click here to download file 'appendix2.xlsx'. 